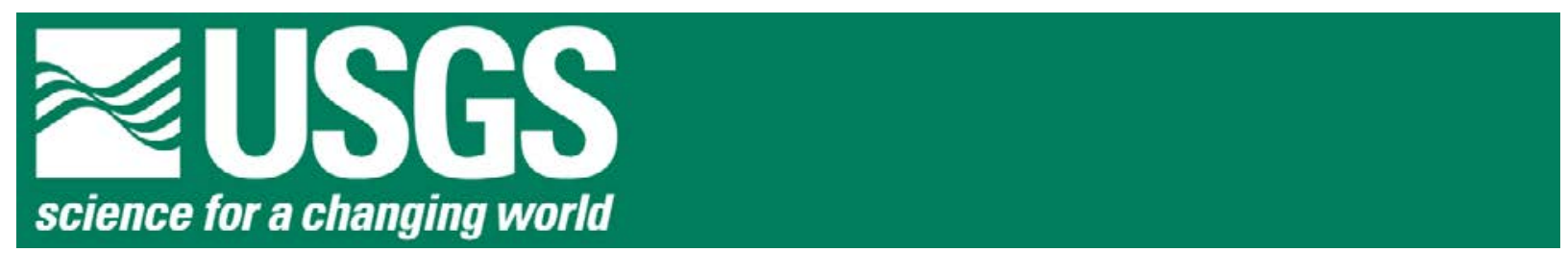

\title{
Nearshore Morphology, Benthic Structure, Hydrodynamics, and Coastal Groundwater Discharge near Kahekili Beach Park, Maui, Hawaii
}

By Peter W. Swarzenski, Curt D. Storlazzi, M. Katherine Presto, Ann E. Gibbs, Christopher G. Smith, Natasha T. Dimova, Meghan L. Dailer, and Joshua B. Logan
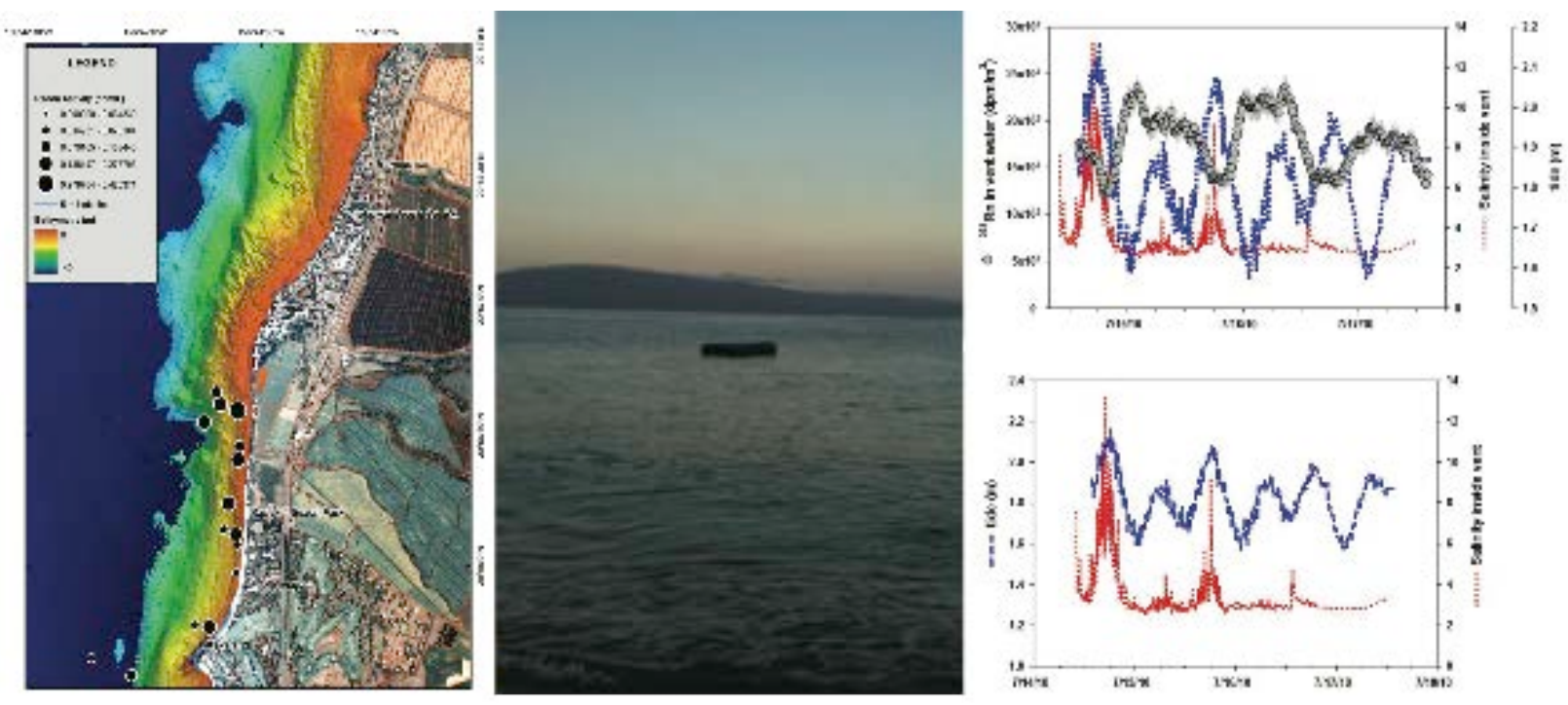

Open-File Report 2012-1166

U.S. Department of the Interior

U.S. Geological Survey 


\section{U.S. Department of the Interior \\ KEN SALAZAR, Secretary}

\section{U.S. Geological Survey \\ Marcia K. McNutt, Director}

U.S. Geological Survey, Reston, Virginia: 2012

For product and ordering information:

World Wide Web: http://www.usgs.gov/pubprod

Telephone: 1-888-ASK-USGS

For more information on the USGS-the Federal source for science about the Earth, its natural and living resources, natural hazards, and the environment:

World Wide Web: http://www.usgs.gov

Telephone: 1-888-ASK-USGS

Suggested citation:

Swarzenski, P.W., Storlazzi, C.D., Presto, M.K., Gibbs, A.E., Smith, C.G., Dimova, N.T., Dailer, M.L., and Logan, J.B., 2012, Nearshore morphology, benthic structure, hydrodynamics, and coastal groundwater discharge near Kahekili Beach Park, Maui, Hawaii: U.S. Geological Survey Open-File Report 2012-1166, 34 p. (Available at http://pubs.usgs.gov/of/2012/1166/.)

Any use of trade, product, or firm names is for descriptive purposes only and does not imply endorsement by the U.S. Government.

Although this report is in the public domain, permission must be secured from the individual copyright owners to reproduce any copyrighted material contained within this report.

Cover: Left, example radon survey map offshore from Kahekili Beach Park, Maui, Hawaii; middle, photo of the radon time-series mooring at Kahekili; and right, example radon activities at the primary vent site at Kahekili. 


\section{Contents}

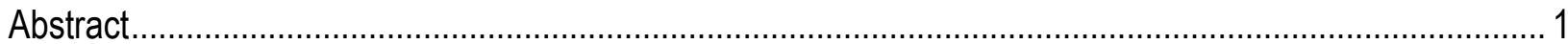

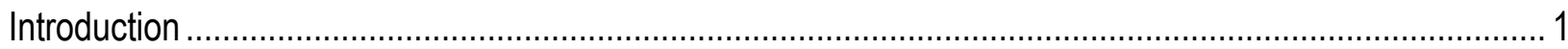

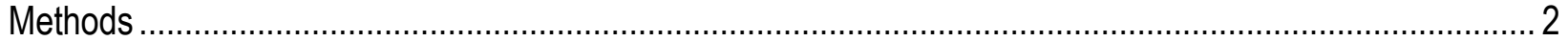

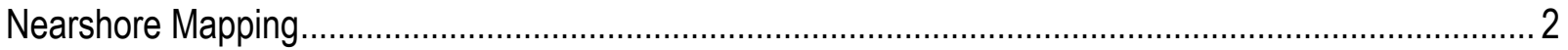

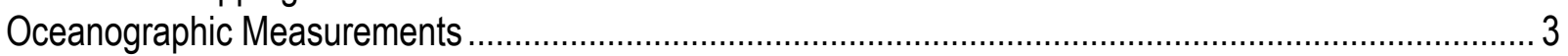

Submarine Groundwater-Discharge Measurements .................................................................... 3

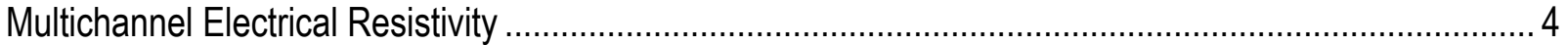

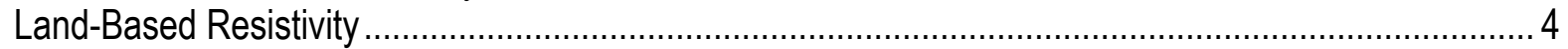

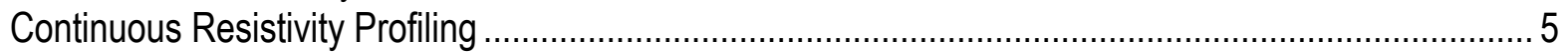

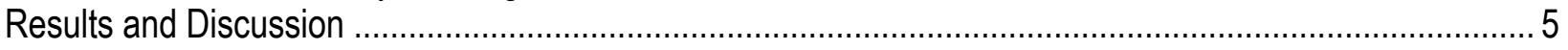

Nearshore Mapping..............................................................................................................

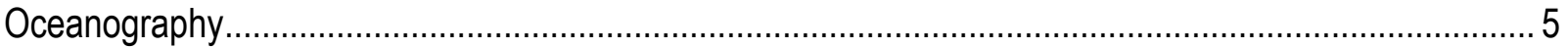

Submarine Groundwater Discharge and Nutrient Loads ............................................................... 6

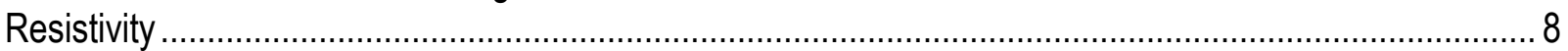

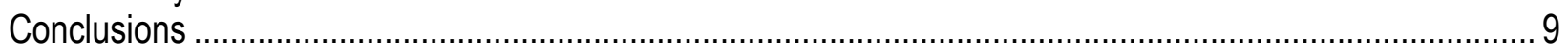

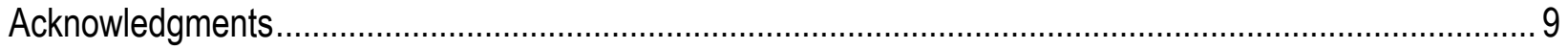

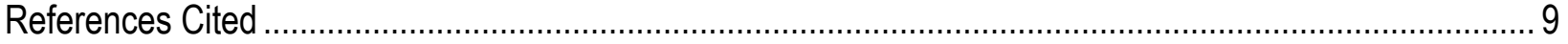

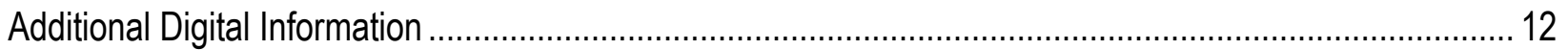

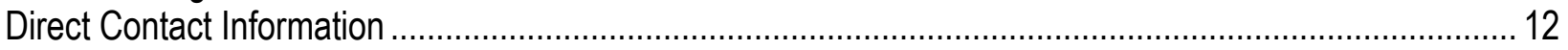

Appendix. Acoustic Doppler Current Profiler (ADCP) Information .......................................................... 12

\section{Tables}

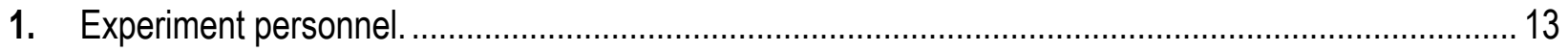

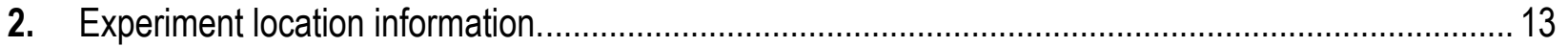

3. Select trace-element concentrations in surface water at the primary vent site at Kahekili Beach

Park......

4. Select trace-element concentrations in discharging vent water at the primary vent site at Kahekili

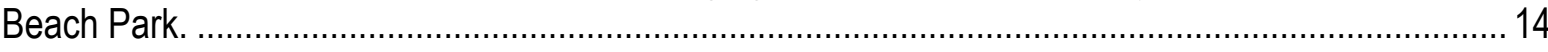

5. Nutrient concentrations in surface water at the primary vent site at Kahekili Beach Park...................14

6. Nutrient concentrations in discharging vent water at the primary vent site at Kahekili Beach Park...... 15

7. Wave statistics at the Acoustic Doppler current profiler (ADCP) site............................................. 15

8. Current and temperature statistics at the Acoustic Doppler current profiler (ADCP) site. .................... 15

9. Mean radon-222 (222Rn) derived submarine groundwater discharge (SGD) rates at the four timeseries moorings at Kahekili Beach Park. ............................................................................ 15

10. Mean discharging groundwater nutrient concentrations in select coastal groundwater systems in Hawaii.

11. Loading estimates per meter of shoreline of nutrient concentrations from select nearshore sites in Hawaii.

\section{Figures}

1. Map depicting Maui, Hawaii, and surrounding islands. Study site is located on the northwest coast of Maui. 
2. Aerial photograph and SHOALS (Scanning Hydrographic Operational Airborne Lidar Survey) lidar bathymetric map of the west Maui study area showing the video and side-scan sonar tracklines....... 18

3. Aerial photograph and SHOALS (Scanning Hydrographic Operational Airborne Lidar Survey) lidar bathymetric map of the west Maui study area showing the location of instruments, resistivity lines, vent sites, and major landmarks.

4. Aerial photograph and SHOALS (Scanning Hydrographic Operational Airborne Lidar Survey) lidar bathymetric map of the west Maui study area showing the location of the continuous resistivity profiling lines.

5. Aerial photograph and SHOALS (Scanning Hydrographic Operational Airborne Lidar Survey) lidar bathymetric map of the west Maui study area overlaid with the side-scan sonar data collected in the study area.

6. Side-scan sonar map and video images of the seafloor in the northern part of the the west Maui study area.

7. Aerial photograph of the west Maui study area showing percent (\%) coral coverage interpreted from the seafloor video imagery. m, meters................................................................................. 23

8. Time-series plots of tide, current, and water temperature data from the Acoustic Doppler current profiler (ADCP) at the primary submarine groundwater vent site.

9. Map showing the mean (vectors) and variability (ellipses) of waves and currents at the primary submarine groundwater vent site.

10. Map showing modeled cumulative flow distance for 3 hours following low tide at the near surface (gray vectors) and near bed (black vectors) at the primary submarine groundwater vent site.

11. Time-series plots of salinity of the discharging submarine groundwater and tide level (in meters, $\mathrm{m})$ at the primary vent site.

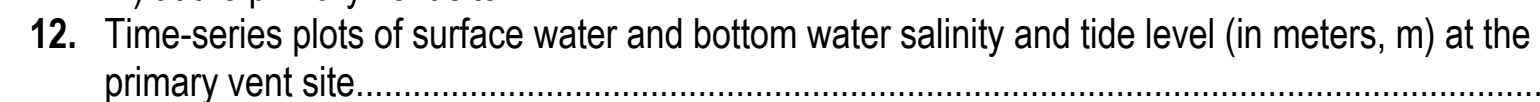

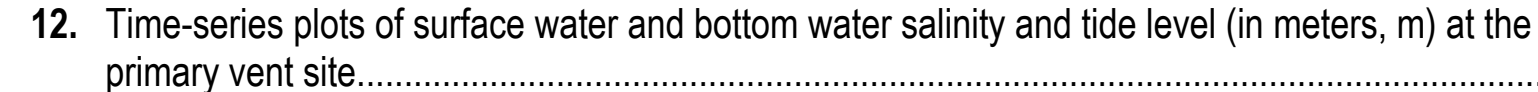

13. Time-series plots of radon-222 (222Rn) activities, in disintegrations per minute per cubic meter of water $\left(\mathrm{dpm} / \mathrm{m}^{3}\right)$, salinity, and tide level, in meters $(\mathrm{m})$, at the primary submarine groundwater vent site .....

14. Time-series plots of surface water radon-222 (222Rn), in disintegrations per minute per cubic meter of water $\left(\mathrm{dpm} / \mathrm{m}^{3}\right)$, and water level, in meters $(\mathrm{m})$, at the primary submarine groundwater vent site.

15. Time-series plots of calculated radon-222 (222Rn)-derived advection rates, in centimeters per day $(\mathrm{cm} / \mathrm{d})$, and salinity for the primary submarine groundwater vent site.

16. Aerial photograph and SHOALS (Scanning Hydrographic Operational Airborne Lidar Survey) lidar bathymetric map of the west Maui study area overlaid with radon-222 (222Rn) activities, in disintegrations per minute per liter of water (dpm/L), in coastal surface waters.

17. Fence diagrams showing continuous resistivity profile results from the shore-parallel transects in the west Maui study area.

18. Fence diagram showing a land-based, multichannel electrical resistivity survey conducted along the beach face in the west Maui study area adjacent to the primary submarine groundwater vent site (horizontal axis is meters). 


\title{
Nearshore Morphology, Benthic Structure, Hydrodynamics, and Coastal Groundwater Discharge near Kahekili Beach Park, Maui, Hawaii
}

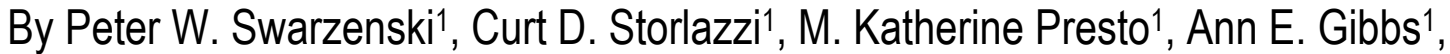 \\ Christopher G. Smith1', Natasha T. Dimova², Meghan L. Dailer ${ }^{3}$, and Joshua B. Logan'1
}

\begin{abstract}
This report presents a brief summary of recent fieldwork conducted off Kahekili Beach Park, Maui, Hawaii, the site of the newly established U.S. Coral Reef Task Force priority study area at Kaanapali and the Hawaii Department of Land and Natural Resources, Division of Aquatic Resources, Kahekili Herbivore Fisheries Management Area (HFMA). The goals of this fieldwork are to provide new baseline information to help guide future studies and to provide first insights into rates and drivers of coastal groundwater discharge and associated constituent loadings into the priority study area's coastal waters. This study presents the first swath acoustic mapping information, in situ oceanographic instrument measurements, and coastal groundwater discharge estimates at this site based on the submarine groundwater discharge tracer radon-222 $\left({ }^{222} \mathrm{Rn}\right)$. Coastal groundwater discharge rates ranged from about 22 to 50 centimeters per day, depending on proximity of the sampling mooring to the primary discharge vent. The water chemistry of the discharging groundwater was at times dramatically different than ambient seawater. For example, at the primary vent site at Kahekili, the concentrations of total dissolved nitrogen (TDN), dissolved silicate (DSi), and total dissolved phosphorus (TDP) in the discharging groundwater were 43.75 micromolar $(\mu \mathrm{M}), 583.49 \mu \mathrm{M}$, and $12.04 \mu \mathrm{M}$, respectively. These data extend our basic understanding of the morphology, benthic structure, and oceanographic setting of this vent site and provide a first estimate of the magnitude and physical forcings of submarine groundwater discharge and associated trace metals and nutrient loads here.
\end{abstract}

\section{Introduction}

The Kaanapali region north of Lahaina in west Maui, Hawaii, is a very popular tourist destination, and the shoreline is consequently largely developed with hotels, resorts, and associated infrastructure. This report presents a brief summary of recent fieldwork done off Kahekili Beach Park in Kaanapali (fig. 1; see table 1 for list of experiment personnel) to better characterize the seafloor, nearshore oceanography, and hydrogeologic exchange processes. This site has just been established as a U.S. Coral Reef Task Force (USCRTF) priority study area and the Hawaii Department of Land and Natural Resources, Division of Aquatic Resources

\footnotetext{
${ }^{1}$ U.S. Geological Survey.

${ }^{2}$ University of Alabama, Department of Geological Sciences, Tuscaloosa, Alabama.

${ }^{3}$ University of Hawaii, Department of Botany, Honolulu, Hawaii.
} 
(DLNR/DAR), Kahekili Herbivore Fisheries Management Area (FMA). Over the past decade, there has been a notable change in bottom type at this location; areas once covered by abundant corals are now covered mostly by turf algae or macroalgae, suggesting a likely local nutrient imbalance that warrants further investigation. Because of this, the site has previously been studied to examine how municipal wastewater plumes may be conveyed to the coastal waters by discharging groundwater (Dailer and others, 2008, 2010; Hunt and Rosa, 2009). At this site there are multiple spring vents close to shore (water depths are usually less than 2 meters), where much lower salinity water can readily be observed discharging into the nearshore water column. Previous efforts have used dissolved nitrate $\left(\delta^{15} \mathrm{~N}\right)$ records (Dailer and others, 2010), as well as a suite of telltale organic pollutants (for example, Hunt and Rosa, 2009), to infer focused municipal wastewater discharges at this location. In 2010, the USCRTF designated the Kaanapali linked watershed-reef system (or "ahupua'a" in Hawaiian) as a USCRTF Hawaiian Local Action Strategy to Address Land-Based Pollution (HI-LBP/LAS) priority study site so that research and restoration could be directed to the area. At the same time, DLNR/DAR established the Kahekili Herbivore Fisheries Management Area (FMA) in an effort to increase the number of herbivores to help reduce the turf algae or macroalgae that have overgrown the corals at the site.

Our study presents the first swath acoustic map, in situ oceanographic instrument measurements, and first estimates of coastal groundwater discharge to this site based on the submarine groundwater discharge tracer radon-222 $\left({ }^{222} \mathrm{Rn}\right)$. These data extend our basic understanding of the morphology, benthic structure, and oceanographic setting of this location, and provide a first estimate of the magnitude and physical forcings of submarine groundwater discharge (SGD) and associated metals and nutrient loads here. The goals of this effort are to provide baseline information for future studies and to assess the viability of proven SGD tracers to assess SGD magnitude and constituent loadings into the area's coastal waters. Based on four surface-water ${ }^{222} \mathrm{Rn}$ time-series measurements that were conducted at the primary vent site and surrounding environs, the groundwater flux was quantified and used to derive constituent loadings for suite of trace elements and nutrients. Loading estimates were also compared to similarly derived load estimates for select other Hawaiian coastal waters.

\section{Methods}

\section{Nearshore Mapping}

Geo-referenced underwater video and side-scan sonar/acoustic backscatter data were collected between Kekaa Point (Black Rock) and the north end of Honokowai (fig. 2) between March 21 and 22, 2011, as part of U.S. Geological Survey (USGS) Field Activity A-2-11-MU (http://walrus.wr.usgs.gov/infobank/a/a0211mu/html/a-02-11-mu.meta.html, last accessed May15, 2012). This fieldwork was reconnaissance in design and not intended to acquire the extent or quality of imagery necessary to perform a comprehensive or quantitative analysis on coral diversity, benthic habitat, or health of the Kahekili-Honokowai reef tract.

Nearly 2 hours of underwater video were collected at 84 stations using a Splashcam Sidewinder 360 video system (http://www.splashcam.com/sidewinder/sw.htm, last accessed May15, 2012). The camera was hand deployed over the side of the boat, at stations that generally corresponded to the 5, 10,15, 20, 25 and 30 meter $(\mathrm{m})$ isobaths, along multiple shore-normal transects. Standard definition National Television System Committee (NTSC) video was recorded to mini-DV videotape in the field. Back in the lab, the video imagery was converted to digital MPEG2 files and adjusted for white balance. Still images were grabbed every 10 seconds 
along individual video tracklines and used to interpret benthic structure following the classification scheme of Battista and others (2007).

Navigation and position information was acquired using a Novatel ProPak-G2plus. National Marine Electronics Association (NMEA) Global Positioning System (GPS) information was recorded on the right audio channel of the videotapes using Red Hen Systems VMS hardware (RHS; http://www.redhensystems.com/, last accessed May15, 2012). This audio encoding allows geolocation of the video imagery and random access to the video in a geographic information system (GIS), using software developed by RHS. Navigation was also recorded to a computer on the fly using RHS Media Mapper software.

Side-scan sonar was collected along 12 lines over an area of 0.92 square kilometer $\left(\mathrm{km}^{2}\right.$; 227 acres) using a Humminbird 898C SI fishfinder system (http://store.humminbird.com/products/341721/898c_SI_Combo, last accessed May15, 2012). Data were processed and an acoustic backscatter image was produced using SonarWiz software (http://chesapeaketech.com/prod-wizmap.html, last accessed May15, 2012).

\section{Oceanographic Measurements}

In situ oceanographic measurements of tides, waves, currents, and water temperature were made July 14-17, 2010, just north of the Kahekili Beach Park (fig. 3; table 2). These measurements were made using a 2-MHz Nortek Aquadopp acoustic Doppler current profiler (ADCP; see appendix for ADCP information) that collected data in $0.25-\mathrm{m}$ bins from $0.5 \mathrm{~m}$ above the seafloor up to the surface for 250 seconds (s) at 2 hertz (Hz) every 5 minutes (min) to allow calculation of tides $(\mathrm{m})$, mean current speeds $(\mathrm{m} / \mathrm{s})$, and mean current directions (in degrees relative to true north). Directional wave data were recorded for 1,024 s at $2 \mathrm{~Hz}$ every hour; these data included wave height (m), wave period (s), and mean wave direction (in degrees relative to true north). Water temperature (in degrees Celsius, ${ }^{\circ} \mathrm{C}$ ) was measured every 5 min.

\section{Submarine Groundwater-Discharge Measurements}

Radon-222 is an effective tracer to assess water transport and exchange processes, such as submarine groundwater discharge, because this isotope has a short half-life $\left(t_{1 / 2}\right)$ of 3.8 days (d), is a noble gas and so chemically inert, and is highly enriched in groundwater relative to surface water (Swarzenski, 2007). Recent advances in the analyses of ${ }^{222} \mathrm{Rn}$ have been greatly simplified by a commercially available $\mathrm{Rn}$-in-air monitor and a simple water/air exchanger that enables one to calculate the aqueous Rn concentration from the measured air concentration (Burnett and Dulaiova, 2003; Dulaiova and others, 2006; Swarzenski and others, 2006). At Kahekili Beach Park, a suite (fig. 3) of geochemical field samples were collected and geophysical surveys conducted over a 1-week period in mid-July 2010. Geochemical analyses of time-series sampling included ${ }^{222} \mathrm{Rn}$, ammonium $\left(\mathrm{NH}_{4}{ }^{+}\right)$, dissolved silicate (DSi), soluble reactive phosphorus (SRP), nitrate-nitrite $\left(\mathrm{NO}_{3}{ }^{-}+\mathrm{NO}_{2}{ }^{-}\right)$, dissolved inorganic nitrogen, (DIN), dissolved organic nitrogen (DON), total dissolve nitrogen (TDN), total dissolved phosphorus (TDP), molybdenum (Mo), barium (Ba), rhenium (Re), vanadium $(\mathrm{V})$, iron $(\mathrm{Fe})$, cesium $(\mathrm{Cs})$, uranium $(\mathrm{U})$, chromium $(\mathrm{Cr})$, and manganese $(\mathrm{Mn})$. Geophysical surveys included both continuous-resistivity-profiling mapping and land-based multichannel electrical resistivity. Select trace-element concentrations (in nanomolars, $\mathrm{nM}$ ) are shown in table 3 (surface water) and table 4 (discharging vent water), whereas select nutrient concentrations (in micromolar, $\mu \mathrm{M}$ ) $\mathrm{s}$ are shown in table 5 (surface water) and table 6 (discharging vent water). 
Time-series measurements of surface water ${ }^{222} \mathrm{Rn}\left(\mathrm{t}_{1 / 2}=3.8 \mathrm{~d}\right)$ were obtained using a single Durridge Company, Inc., RAD7 radon monitor set to 30-min counting intervals and were modeled to derived total (fresh+brackish) SGD rates (Burnett and Dulaiova, 2003; Burnett and others, 2001, 2006) at the primary vent site and also at three additional sites surrounding the main vent. The purpose of these deployments was to observe how SGD rates may vary spatially and within different benthic structures. Using methods described in Swarzenski and others (2007b), nutrients were determined on a Lachat Instruments QuickChem 8000, and the suite of trace elements was analyzed on a HR-ICPMS at University of Southern Mississippi.

To adequately capture discharging vent water, a piezometer was carefully inserted into a prominent spring vent by a diver using scuba to minimize contamination of the discharging groundwater by ambient seawater. Time-series measurements of ${ }^{222} \mathrm{Rn}$, as well as of nutrients and select trace elements, were collected from this piezometer and complimented with concurrent surface water samples. Water quality parameters were monitored using a calibrated YSI multiprobe. In all instances, the dissolved oxygen concentrations in groundwater samples were close to 1 milligram per liter ( $\mathrm{mg} / \mathrm{L}$ ) (strongly sub-oxic), indicating that the groundwater samples were not compromised by seawater intrusion.

\section{Multichannel Electrical Resistivity}

Electrical resistivity techniques are often used to measure the conductivity (resistivity $=$ electrical conductivity ${ }^{-1}$ ) of coastal sediment and pore fluids and have recently proven useful for assessments of the detailed dynamics of the freshwater/saltwater interface with the development of multichannel resistivity systems (Manheim and others, 2004; Swarzenski and others, 2004, 2006; Dimova and others, 2012). Advantages of these newer systems include tailored stream arrays, rapid data acquisition, and user-friendly post-processing software. The resistivity measurements were post-processed using an updated inverse modeling routine within Advanced Geosciences, Inc. (AGI), EarthImager software that accommodates the water-column salinity and depth. Processing resolution was optimized by using a starting model with the apparent resistivity pseudosection coupled to real bathymetry and topography data. A best-fitting layered model was then developed using an iterative least-squares smooth-model inversion method (Swarzenski and others, 2007b).

\section{Land-Based Resistivity}

At Kahekili Beach Park, the resistivity of the underlying beach sediment was surveyed using an AGI, eight-channel Marine SuperSting R8 system connected to an external switching box that controlled the flow of current along the 56-electrode cable. This system was programmed to measure current potentials in a distributed array so that resolution and signal-tonoise ratio is maximized. For one resistivity measurement, the receiver injects an optimized current, reverses the polarity and then re-injects the current again to cancel potential spontaneous voltages. This process was repeated until the error is below a prescribed threshold value. Landbased electrical-resistivity surveys were conducted along the beach face adjacent to the primary vent site as well as at two adjacent mooring sites. For this work, the electrical resistivity streamer was placed just landward of the high tide line (Swarzenski and others, 2006, 2007a,b). Current flow was routed down-cable from a user-defined command file using a dipole-dipole configuration. These settings enabled the collection of more than 760 discrete resistivity readings in less than $25 \mathrm{~min}$. Recent applications of this geophysical tool have ranged from creating hydrogeologic perspectives (Bratton, 2011) to qualitative identification of groundwater seepage 
sites (Day-Lewis, 2006, Swarzenski, 2007), and actual SGD assessments (Swarzenski and others, 2006; Dimova and others, 2012).

\section{Continuous Resistivity Profiling}

Continuous resistivity profiling (CRP) is the unique adaption of a common geophysical technique to measure the electrical resistivity of sediment beneath a water body such as river, lake, or the coastal ocean. An advantage of this method is that relatively long transects (tens of kilometers) can be surveyed from a small boat with access to very shallow water. Most of the interest in these towed-array resistivity measurements comes from coastal scientists and hydrologists that are interested in the dynamics of the freshwater/saltwater interface and general hydrogeological controls of coastal aquifers.

A CRP survey was made of the nearshore region off Kahekili Beach Park to help confirm the regional extent of discharging groundwater (fig. 4). Surveys were done using the AGI SuperSting R8/IP and a 120-m long towed cable specifically designed for marine resistivity acquisition. The cable consists of two current electrodes and nine potential electrodes with 10-m spacing. Total depth penetration below the sea bottom using this electrode spacing and dipoledipole configuration is approximately $25 \mathrm{~m}$ but is water depth dependent. The real-time position of the boat was streamed directly to the SuperSting from a Lowrance LMS-480 GPS. Basic water quality parameters and ${ }^{222} \mathrm{Rn}$ were also measured during these surveys. Temperature and specific conductance were measured using a YSI-556 probe mounted $0.5-\mathrm{m}$ below the water surface. Radon-222 was measured using three RAD7 radon-in-air monitoring devices that were connected in parallel to one air/gas exchanger, as described by Dulaiova and others (2006). Briefly, surface water was pumped to an air/water exchanger where the radon in water was aspirated into the gas phase and drawn into the three RAD7s. Radon-in-air concentration was converted to radon-in-water concentration using the exchanger temperature and a computed partitioning coefficient (Burnett and others 2001).

\section{Results and Discussion}

\section{Nearshore Mapping}

Preliminary evaluation of the underwater video and acoustic backscatter imagery suggest the Kahekili/Honokowai reef tract supports medium to high coral cover from just south of Kahekili Beach Park to the northern extent of our survey in north Honokowai, with the densest coral cover observed offshore of Honokowai Point and Kahekili Beach Park (figs. 5, 6). The dominant coral species observed included Porites compressa, Porites lobata, Montipora capitata, and Pocillopora meandrina. Live coral is restricted to water depths between approximately 3 and $20 \mathrm{~m}$, with highest coral coverage between 10 and $15 \mathrm{~m}$ (fig. 7). In water depths greater than about $20 \mathrm{~m}$, the seafloor is dominated by sand colonized with the calcified green algae Halimeda sp. South of Kahekili Beach Park, the seafloor transitioned to an extensive sheet of uncolonized, rippled sand and undulating, uncolonized carbonate pavement.

\section{Oceanography}

Oceanographic data were acquired for 61 hours over more than 2 days during the period from July 14 to 17, 2010 (2010 Year Days 195.75-198.25). More than 10,000 data points were recorded by the ADCP. The raw data were archived and copies of all the data were postprocessed for analysis. The ADCP data generally appeared to be of high quality. 
The tides of west Maui are mixed, semidiurnal (Storlazzi and Jaffe, 2008); the maximum tidal range during the deployment was $0.74 \mathrm{~m}$ (fig. 8), transitioning from spring to neap tide conditions. The wave heights decreased slightly during the deployment, ranging from 0.31 to $0.78 \mathrm{~m}$, with a mean \pm 1 standard deviation of $0.50 \pm 0.12 \mathrm{~m}$ (table 7 ). The wave periods and directions varied a bit around the mean but showed no long-term trends during the deployment, ranging from $4.2 \mathrm{~s}$ to $11.0 \mathrm{~s}$ and from $225.9^{\circ}$ to $263.6^{\circ}$, with a mean \pm 1 standard deviation of $8.2 \pm 1.6 \mathrm{~s}$ and $233.9 \pm 34.0^{\circ}$, respectively. The currents appear to be primarily driven by the tides, and the current speeds decreased slightly during the deployment, likely due to the decrease in tidal range (fig. 8). The near-surface and near-seabed current speeds ranged from $0.01 \mathrm{~m} / \mathrm{s}$ to $0.11 \mathrm{~m} / \mathrm{s}$ and from $0.00 \mathrm{~m} / \mathrm{s}$ to $0.09 \mathrm{~m} / \mathrm{s}$, with a mean \pm 1 standard deviation of $0.05 \pm 0.02 \mathrm{~m} / \mathrm{s}$ and $0.04 \pm 0.02 \mathrm{~m} / \mathrm{s}$, respectively (table 8 .) Whereas the primary orientation of flow was alongshore, likely due to tidal forcing, the mean current direction throughout most of the water column at the deployment site was directed offshore to the west-southwest, likely balancing the net wavedriven onshore flow to the east-northeast (figs. 9, 10). The water temperatures appeared primarily driven by the daily insolation cycle, peaking in the afternoon and reaching a minimum in the early morning, with no apparent long-term trend over the short deployment. Over the course of the deployment, the water temperature ranged from 20.62 to $22.24^{\circ} \mathrm{C}$, with a mean \pm 1 standard deviation of $21.28 \pm 0.38^{\circ} \mathrm{C}$ (table 8 ). For more information on tides, waves, currents, and water-column properties along west Maui, see Storlazzi and others (2003, 2006), Storlazzi and Field (2008), and Storlazzi and Jaffe (2003, 2008).

\section{Submarine Groundwater Discharge and Nutrient Loads}

Salinity of the discharging vent water varied directly with the tide and was surprisingly fresh, although the salinity fluctuated from under 2 to more than 12 (fig. 11). Ambient seawater salinities above the vents were consistently between 34 and 36, indicating only slight freshening relative to open-ocean salinities (fig. 12). The surface water is noticeably lower in salinity than bottom water during much of the time series. The mean ${ }^{222} \mathrm{Rn}$ activity in the vent water showed inverse systematic variations with the tide (fig. 13). A representative value of the discharging vent water (that is, groundwater) ${ }^{222} \mathrm{Rn}$ activity (27,045 disintegrations per minute per cubic meters, $\mathrm{dpm} / \mathrm{m}^{3}$ ) was used in the calculation of submarine groundwater discharge rates at all four surface water sites at Kahekili. Figure 14 shows the ${ }^{222} \mathrm{Rn}$ time-series results for the surface water at the primary vent site. Although there are systematic fluctuations in ${ }^{222} \mathrm{Rn}$ that appear to be modulated by the tidal stage, the surface water ${ }^{222} \mathrm{Rn}$ activities are quite low (fig. 14). Acknowledging the various assumptions that are inherent in the application of a $\mathrm{Rn}$ box model (Burnett and Dulaiova, 2003; Burnett and others, 2001, 2003, 2006, 2007; Dulaiova and others, 2006; Swarzenski and others, 2006, 2007a,b, 2009) to derive a rate of SGD, the calculated SGD rate was highest (mean $=55 \pm 56 \mathrm{~cm} / \mathrm{d} ; \max =277 \mathrm{~cm} / \mathrm{d}$; fig. 15) at the primary vent site (fig. 15) and consistently lower at the three surrounding sites (table 9). The three more distal Rn mooring sites were chosen based on bottom sediment/bedrock type as well as distance from the main vent site; site A targeted sand deposits, site B was situated seaward of the primary vent site to discern the potential offshore extent of the discharge field, and site $\mathrm{C}$ targeted volcanic outcrops. Based on these radon data as well as simple visual observations, it appears that groundwater discharge was most pronounced at the shallow active vent site but is still enhanced at least out to the most distal Rn-mooring site (site B). This suggests that discharge may not be contained only within the shallow vent sites but may be more regional in scale.

Based on the peaks in ${ }^{222} \mathrm{Rn}$ activity (fig. 13) at and in the 3 hours following low tides, a rough estimate of the distance and direction of submarine groundwater discharged into the 
nearshore at the vent site can be made using a series of 3-hour progressive vector diagrams of projected cumulative flow starting from the vent site at low tide. These progressive vector diagrams were constructed using the method described by Siegel and others (2003) during the study period (fig. 10). These calculations make the assumption that the flow measured at Kahekili is uniform alongshore and cross shore from the vent site, which is not always the case (Storlazzi and others 2006; Storlazzi and Field, 2008). The projections do, however, provide information regarding the relative direction and magnitude of flow and the flux of nutrient-laden submarine groundwater discharged from the vent during the projected time period if the forcing mechanisms (wind and tides) were to remain uniform over the projected travel path. Our measurements off Kahekili showed that there was net alongshore flow, and therefore net transport of nutrient-laden water, to the south from the vent site towards Keka'a (Black Rock) Point during the 3 hours following low tides when the SGD rate was the greatest.

The majority of the radon data collected during the CRP surveys was near the limits of detection for the multidetector instrumentation. The highest surface water radon activity measured was $0.4 \mathrm{dpm} / \mathrm{L}$ (fig. 16). This is likely attributable to the deep water column that would considerably dilute any focused high Rn groundwater source. Another prominent factor in these low Rn numbers is probably a result of the sea state at the time of sampling; unfortunately, the prevailing winds were consistently strong and created relatively large waves that disrupted the air/sea interface.

In addition to the surface-water and groundwater ${ }^{222} \mathrm{Rn}$ time-series data, discrete surfacewater and groundwater samples were also collected on July 14, 2011, at the primary vent site. Tables 3 and 4 report associated select trace-element analyses (in nM) obtained during this sampling. The discharging vent water was strongly depleted in dissolved oxygen (as measured with a YSI multiprobe; data not shown), which was also manifested in some of the observed redox-sensitive trace-element concentrations (that is, Mn, U, V, and Mo). In contrast, Fe does not appear enriched in the reduced groundwater. Some trace element concentrations (for example, $\mathrm{Fe}, \mathrm{Cr}$, and $\mathrm{Mn}$ ) increased after the 10:00 a.m. Hawaii Standard Time (HST) low-tide event, verifying that the tide modulates groundwater discharge rates.

Nutrient $\left(\mathrm{NH}_{4}, \mathrm{DSi}, \mathrm{SRP}, \mathrm{DIN}, \mathrm{DON}, \mathrm{TDN}\right.$, and TDP) concentrations $(\mu \mathrm{M})$ in surface water and discharging vent water, respectively, are summarized in tables 5 and 6 . Very little ammonia was present either in the surface water (mean concentration=0.07 $\mu \mathrm{M}$ ) or discharging groundwater (mean concentration $=0.3 \mu \mathrm{M}$ ). Mean silica concentrations were roughly 36 -fold greater in discharging groundwater $($ mean $=583.5 \mu \mathrm{M})$ than ambient surface seawater $($ mean $=15.97 \mu \mathrm{M})$. Dissolved inorganic nitrogen (DIN) concentrations were also much higher in discharging groundwater (mean $=34.8 \mu \mathrm{M}$ ) than in ambient surface seawater (mean=0.2 $\mu \mathrm{M}$ ); this trend was also observed for unacidified $\mathrm{PO}_{4}$ (Total Dissolved Phosphorus, TDP) where the mean groundwater concentration was $12.04 \mu \mathrm{M}$ and the mean surface seawater concentration was $0.11 \mu \mathrm{M}$. Mean unacidified $\mathrm{PO}_{4}$ (as soluble reactive phosphorus, SRP) concentrations in the discharging groundwater $(11.41 \mu \mathrm{M})$ were comparable to mean TDP values. The N:P (DIN/SRP) molar ratio for discharging groundwater was between 1.8 and 3.5 (mean=2.98) and the mean surface seawater value was 5.5 .

One can use mean coastal groundwater nutrient concentrations (table 10) and calculated SGD rates to derive submarine groundwater discharge-associated nutrient loading estimates into nearshore waters (Garrison and others, 2003; Swarzenski and Izbicki, 2009; Johnson and others, 2008; Peterson and others, 2009; Knee and others, 2010). The calculated mean SGD rate for the 
primary vent site at Kahekili Beach Park $\left(55 \mathrm{~cm} \mathrm{~d}^{-1}\right.$ or $55 \mathrm{~m}^{3} / \mathrm{d} / \mathrm{m}$ of shoreline assuming that the discharge extends out to $100 \mathrm{~m}$ ) is on the same order of magnitude as the Rn-derived SGD rates obtained recently for two sites in Maunalua Bay, Oahu (Black Point $=33.1 \mathrm{~m}^{3} / \mathrm{d} / \mathrm{m}$ and Niu=29.8 $\mathrm{m}^{3} / \mathrm{d} / \mathrm{m}$ ) (Swarzenski and others, 2009), as well as two additional SGD rate estimates reported in Johnson and others (2008) and Peterson and others (2009) for the Kona coast of Hawaii, 133.9 $\mathrm{m}^{3} / \mathrm{d} / \mathrm{m}$ and $86.5 \mathrm{~m}^{3} / \mathrm{d} / \mathrm{m}$, respectively.

From these SGD rates, the following SGD-derived nutrient loading estimates are calculated for the primary vent site at Kahekili per meter of shoreline: $\mathrm{NH}_{4}{ }^{+}, 0.02 \mathrm{~mol} / \mathrm{d} / \mathrm{m}$; DSi, $32 \mathrm{~mol} / \mathrm{d} / \mathrm{m}$; SRP, $0.70 \mathrm{~mol} / \mathrm{d} / \mathrm{m}$; [NO $\left.\mathrm{NO}_{2}+\mathrm{NO}_{3}{ }^{-}\right], 2.18 \mathrm{~mol} / \mathrm{d} / \mathrm{m}$; DIN, $2.2 \mathrm{~mol} / \mathrm{d} / \mathrm{m} ; \mathrm{DON}, 0.54$ $\mathrm{mol} / \mathrm{d} / \mathrm{m}$; TDN, $2.73 \mathrm{~mol} / \mathrm{d} / \mathrm{m}$; and TDP, $0.67 \mathrm{~mol} / \mathrm{d} / \mathrm{m}$. Table 11 summarizes these results from the vent site at Kahekili and compares them to similarly obtained SGD-derived nutrient fluxes at Niu and Black Point in Maunalua Bay, Oahu.

\section{Resistivity}

In the shallow waters off Kahekili, focused submarine groundwater discharge provides a direct conduit for the coastal aquifer to readily exchange with the nearshore water column.

Changes in the pore-water resistivity cause a large increase in the resistivity according to wellknown empirical laws governing the resistivity in porous rocks. For example, Archie's Law relates bulk resistivity (ohm meter, $\Omega \bullet \mathrm{m}$ ) of a porous rock to a formation factor, as follows:

$$
\rho_{\mathrm{T}}=\rho_{\mathrm{f}} F ; F=\Phi^{-\mathrm{m}}
$$

where

$\rho_{\mathrm{T}}=$ the bulk resistivity $(\Omega \bullet \mathrm{m})$ of the saturated material,

$\rho_{\mathrm{f}}=$ the resistivity $(\Omega \cdot \mathrm{m})$ of the pore fluid,

$F=$ Formation Factor (unitless),

$\Phi=$ fractional porosity of matrix material, and

$m=$ a empirical exponent based on lithology.

On the basis of Archie's Law, one can estimate that the bulk resistivity of a unconsolidated sand layer $(m=\sim 2)$ may be approximately four times the resistivity of the seawater (typically about $0.3 \Omega \cdot \mathrm{m}$ ). Deviations from this may be interpreted in terms of a hydrologic control (that is, the presence of a freshened water parcel).

Depth penetration below the sediment surface varied considerably during the survey because of the steep offshore seafloor gradient at Kaanapalii Beach. Water depths varied between 5 and $15 \mathrm{~m}$, restricting the surveys to the upper $20 \mathrm{~m}$ of the sub-seafloor or less. Approximately six north-south lines, 2 kilometers $(\mathrm{km})$ each, were surveyed parallel to the Kaanaplii Beach area. Data are shown in figure 17 for four of the six lines collected. Lines beyond approximately $100 \mathrm{~m}$ from the shore had reasonably constant resistivity values (average $=0.61 \Omega \cdot \mathrm{m}$ ) due in part to deeper water and homogenous subsurface. The most nearshore line provides some indication of more resistive units in the subsurface $\left(\rho_{\mathrm{T}}>2.5 \Omega \cdot \mathrm{m}\right)$. One resistive body occurred at the southern end of the embayment where a channelized drainage lagoon at Keka'a (Black Rock Point) provides a hydrogeologic anomaly. The second resistive unit occurs approximately half-way along the shoreline, in a region known for groundwater seepage. The unit is less resistant $(\sim 2.0 \Omega \cdot \mathrm{m})$ than the unit to the south $(>2.5 \Omega \cdot \mathrm{m})$ but is considerably different than elsewhere in the bay $(0.61 \Omega \cdot \mathrm{m})$.

One processed land-based electrical resistivity image is shown in figure 18. Based on this model, a sharp contact is observed along the entire line roughly $2-5 \mathrm{~m}$ below the beach face. It is likely that this contact represents a transition between surficial beach sands and deeper 
geologic deposits. These deeper layers are likely hydraulically transmissive limestone, caprock, and gravel alluvium that is situated variably on top of older volcanic-rock aquifers. Groundwater could be conveyed in these deposits towards the coast where they would rise to the surface due their density contrast with seawater (Manheim and others, 2004; Swarzenski and others, 2006, 2007a,b).

\section{Conclusions}

The seabed in the study area was characterized by dense coral cover offshore of Honokowai Point and Kahekili Beach Park between depths of 3 and 20 m, with the highest coral coverage between 10 and $15 \mathrm{~m}$. In water depths greater than about $20 \mathrm{~m}$, the seafloor was dominated by sand colonized with Halimeda sp. South of Kahekili Beach Park, the seafloor was primarily an extensive sheet of uncolonized, rippled sand and undulating, uncolonized carbonate pavement. Overall, the primary orientation of currents at the deployment site was alongshore, likely due to tidal forcing. The mean current direction throughout most of the water column was directed offshore to the west-southwest, likely balancing the net wave-driven onshore flow to the east-northeast.

The discharging groundwater at the primary vent site north of Kahekili Beach Park was successfully captured using a piezometer that was installed into an active spring vent. This piezometer was used to collect continuous ${ }^{222} \mathrm{Rn}$ measurements as well as discrete water samples. A suite of nutrients and trace elements was obtained in this discharging groundwater and also compared to ambient surface seawater. Surface water ${ }^{222} \mathrm{Rn}$ was monitored for at least several days at the primary vent site, as well as at three surrounding sites that were chosen on the basis of bottom sediment/bedrock type and distance to land. $\mathrm{A}^{222} \mathrm{Rn}$ mass balance model was used to develop submarine groundwater discharge rates at the four surface water moorings. Mean advective rates were predictably highest at the primary vent site $\left(55 \mathrm{~m}^{3} / \mathrm{d} / \mathrm{m}\right)$ and decreased systematically in the surrounding sites $\left(A=21 \mathrm{~m}^{3} / \mathrm{d} / \mathrm{m} ; B=30 \mathrm{~m}^{3} / \mathrm{d} / \mathrm{m}\right.$, and $\left.C=22 \mathrm{~m}^{3} / \mathrm{d} / \mathrm{m}\right)$. During the limited period of in situ measurements, these discharged waters were advected to the south from the vent site. Such observations provide preliminary information as to the scale, magnitude, and constituent loadings of submarine groundwater discharge into nearshore coastal waters off Kahekili Beach Park and can be used to develop subsequent sampling strategies.

\section{Acknowledgments}

This research was conducted under the USGS Submarine Groundwater and USGS Coral Reef Projects, both of which are funded by the USGS Coastal and Marine Geology Program. We would like to thank Russell Sparks and Darla White (HI-DLNR/Division of Aquatic Resources) for invaluable logistical support and Chip Hunt (USGS) for constructive discussions that helped define the field campaign.

\section{References Cited}

Battista, T.A., Costa, B.M., and Anderson, S.M., 2007, Shallow-water benthic habitats of the main eight Hawaiian Islands: Silver Spring, Md., National Oceanic and Atmospheric Administration Technical Memorandum NOS NCCOS 61, DVD.

Bratton, J.F., 2010, Three scales of submarine groundwater flow and discharge across passive continental margins: Journal of Geology, v.118, p. 565-575. 
Burnett, W.C., Aggarwal, P.K., Bokuniewicz, H., Cable, J.E., Charette, M.A., Kontar, E., Krupa, S., Kulkarni, K.M., Loveless, A., Moore, W.S., Oberdorfer, J.A., Oliveira, J., Ozyurt, N., Povinec, P., Privitera, A.M.G., Rajar, R., Ramessur, R.T., Scholten, J., Stieglitz, T., Taniguchi, M., Turner, J.V., 2006, Quantifying submarine groundwater discharge in the coastal zone via multiple methods: Science of the Total Environment, v. 367, p. 498-543.

Burnett, W.C., Cable, J.E., and Corbett, D.R., 2003, Radon tracing of submarine groundwater discharge in coastal environments, in Taniguchi, M., Wang, K., and Gamo, T., eds., Land and marine hydrogeology: Elsevier Publications, p. 25-43.

Burnett, W.C., and Dulaiova, H., 2003, Estimating the dynamics of groundwater input into the coastal zone via continuous radon-222 measurements: Journal of Environmental Radioactivity, v. 69, p. 21-35.

Burnett, W.C., Kim, G., and Lane-Smith, D., 2001, A continuous radon monitor for assessment of radon in coastal ocean waters: Journal of Radioanalytical and Nuclear Chemistry, v. 249, p. 167-172.

Burnett, W.C., Santos, I., Weinstein, Y., Swarzenski, P.W., and Herut, B., 2007, Remaining uncertainties in the use of Rn-222 as a quantitative tracer of submarine groundwater discharge, in Sanford, W., Langevin, C., Polemio, M., and Povinec, P., eds., A new focus on groundwater-seawater interactions: International Association of Hydrological Sciences Publication 312, p. 109-118.

Dailer, M.L., Knox, R.S., Smith, J.E., Napier, M., and Smith, C.E., 2010, Using $\delta^{15} \mathrm{~N}$ values in algal tissue to map locations and potential sources of anthropogenic nutrient inputs on the island of Maui, Hawai'i, USA: Marine Pollution Bulletin, v. 60, p. 655-671, ISSN 0025326X, 10.1016/j.marpolbul.2009.12.021.

Dailer, M.L., Smith, C.E., Smith, J.E., and Brown, D., 2008, Examining $\delta^{15} \mathrm{~N}$ values of intertidal macroalgae on Maui to identify locations and potential sources of nutrient enrichment, in Celia Smith, principal investigator, Integrated Ecosystem Management, Maui (project summary): Honolulu, University of Hawaii, accessed November 4, 2009, at http://www.hawaii.edu/ssri/hcri/files/research/pdf/Smith-FY07-HCRI-NOAAReport1.doc.

Day-Lewis, F.D., White, E.A., Johnson, C.D., and Lane, J.W., Jr., 2006, Continuous resistivity profiling to delineate submarine groundwater discharge - examples and limitations: The Leading Edge, v. 25, p. 724-728.

Dimova, N.T., Swarzenski, P.W., Dulaiova, H., and Glenn, C., 2012, Utilizing multi-channel electrical resistivity methods to examine the dynamics of the freshwater-saltwater interface in two Hawaiian groundwater systems: Journal Geophysical Research, v. 117, C02012, 12 p., doi:10.1029/2011JC007509.

Dulaiova, H., Burnett, W.C., Chanton, J.P., Moore, W.S., Bokuniewicz, H.J., Charette, M.A., and Sholkovitz, E., 2006, Assessment of groundwater discharges into West Neck Bay, New York, via natural tracers: Continental Shelf Research, v. 26, p. 1971-1983.

Garrison, G.H., Glenn, C.R., and McMurtry, G.M., 2003, Measurement of submarine groundwater discharge in Kahana Bay, O`ahu, Hawai'i: Limnology and Oceanography, V. 48, p. 920-928.

Hunt, C.D. Jr. and Rosa, S.N., 2009, A multitracer approach to detecting wastewater plumes from municipal injection wells in nearshore marine waters at Kihei and Lahaina, Maui, Hawaii: U.S. Geological Survey Scientific Investigations Report 2009-5253, 166 p., accessed May 17, 2012, at http://pubs.usgs.gov/sir/2009/5253/. 
Johnson, A.G., Glenn, C.R., Burnett, W.C., Peterson, R.N., and Lucey, P.G., 2008, Aerial infrared imaging reveals large nutrient-rich groundwater inputs to the ocean: Geophysical Research Letters, v. 35, p. L15606, doi:10.1029/2008GL034574.

Knee, K.L., Street, J.H., Grossman, E.E., Boehm, A.B., and Paytan, A., 2010, Nutrient inputs to the coastal ocean from submarine groundwater discharge in a groundwater-dominated system - Relation to land use (Kona coast, Hawai'i, USA): Limnology and Oceanography, v. 55, no. 3, p. 1105-1122.

Manheim, F.T., Krantz, D.E., and Bratton, J.F., 2004, Studying groundwater under DELMARVA coastal bays using electrical resistivity: Groundwater, v. 42, p. 1052-1068.

Peterson, R.N., Burnett, W.C., Glenn, C.R., and Johnson, A.G., 2009, Quantification of pointsource groundwater discharges to the ocean from the shoreline of the Big Island, Hawai' $i$ : Limnology and Oceanography, v. 54, p. 890-904.

Siegel, D.A., Kinlan, B.P., and Gaines, S.D., 2003, Lagrangian descriptions of marine larval dispersion: Marine Ecology Progress Series, v. 260, p. 83-96.

Storlazzi, C.D., and Jaffe, B.E., 2003, Coastal circulation and sediment dynamics along west Maui, Hawaii-Part I, Long-term measurements of currents, temperature, salinity and turbidity off Kahana, west Maui-2001-2003. U.S. Geological Survey Open-File Report 03-482, 28 p., accessed May 17, 2012, at http://pubs.usgs.gov/of/2003/of03-482/.

Storlazzi, C.D., and Jaffe, B.E., 2008, The relative contribution of processes driving variability in flow, shear, and turbidity over a fringing coral reef - west Maui, Hawaii: Estuarine Coastal and Shelf Science, v. 77, no. 4, p. 549-564.

Storlazzi, C.D., and Field, M.E., 2008, Winds, waves, tides, and the resulting flow patterns and fluxes of water, sediment, and coral larvae off west Maui, Hawaii: U.S. Geological Survey Open-File Report 2008-1215, 13 p., accessed May 17, 2012, at http://pubs.usgs.gov/of/2008/1215/.

Storlazzi, C.D., Logan, J.B., McManus, M.A., and McLaughlin, B.E., 2003, Coastal circulation and sediment dynamics along west Maui, Hawaii-Part II, Hydrographic Survey Cruises A-3-03-HW and A-4-03-HW Report on the spatial structure of currents, temperature, salinity, and turbidity along western Maui: U.S. Geological Survey Open-File Report 03430, 50 p., accessed May 17, 2012, at http://pubs.usgs.gov/of/2003/of03-430/.

Storlazzi, C.D., McManus, M.A., Logan, J.B., and McLaughlin, B.E., 2006, Cross-shore velocity shear, eddies, and heterogeneity in water column properties over fringing coral reefswest Maui, Hawaii: Continental Shelf Research, v. 26, p. 401-421.

Swarzenski, P.W., 2007, U/Th series radionuclides as tracers of coastal groundwater: Chemical Reviews, v. 107, no. 2, p. 663-674, doi: 10.1021/cr0503761.

Swarzenski, P.W., Burnett, B., Reich, C., Dulaiova, H., Peterson, R. and Meunier, J., 2004, Novel geophysical and geochemical techniques to study submarine groundwater discharge in Biscayne Bay, Florida: U.S. Geological Survey Fact Sheet 2004-3117, 4 p., accessed July 9 , 2012, at http://sofia.usgs.gov/publications/fs/2004-3117/FS-2004-3117-geophys-techverIII.pdf.

Swarzenski, P.W., Burnett, W.C., Weinstein, Y., Greenwood, W.J., Herut, B., Peterson, R., and Dimova, N., 2006, Combined time-series resistivity and geochemical tracer techniques to examine submarine groundwater discharge at Dor Beach, Israel: Geophysical Research Letters, v. 33, L24405, 6 p., doi:10.1029/2006GL028282.

Swarzenski, P.W., and Izbicki, J,A., 2009, Examining coastal exchange processes within a sandy beach using geochemical tracers, seepage meters and electrical resistivity: Estuarine, Coastal and Shelf Science, v. 83, p. 77-89, doi:10.1016/j.ecss.2009.03.027. 
Swarzenski, P.W., Izbicki, J.A., Grossman, E.E., Glenn, C.R., Plath, C.A., and Kelly, J.L., 2009, A multiproxy tracer approach to submarine groundwater discharge studies-Examples from Santa Barbara, CA and Maunalua Bay, Oah'u, HI: Geochimica et Cosmochimica Acta, v. 73, p. A1299-A1299.

Swarzenski, P.W., Kruse, S., Reich, C., and Swarzenski, W.V., 2007a, Multi-channel resistivity investigations of the fresh water/saltwater interface-A new tool to study an old problem, in Sanford, W., Langevin, C., Polemio, M., and Povinec, P., eds., A new focus on groundwater-seawater interactions: International Association of Hydrological Sciences Publication 312, p. 100-108.

Swarzenski, P.W., Simonds, F.W., Paulson, T., Kruse, S., and Reich, C., 2007b, A geochemical and geophysical examination of submarine groundwater discharge and associated nutrient loading estimates into Lynch Cove, Hood Canal, WA: Environmental Science and Technology v. 41, p. 7022-7029.

\section{Additional Digital Information}

For additional information on the instrument deployments, please see:

For an online PDF version of this report, please see:

http://pubs.usgs.gov/of/2012/1166/

For more information on the U.S. Geological Survey Western Region's Coastal and Marine Geology Team, please see:

http://walrus.wr.usgs.gov/

For more information on the U.S. Geological Survey's Coral Reef Project, please see:

http://coralreefs.wr.usgs.gov/

\section{Direct Contact Information}

General Project Information

Peter W. Swarzenski (USGS Coastal Aquifer Project Chief):

pswarzen@usgs.gov

General Project Information:

Curt Storlazzi (USGS Coral Reef Project Chief):

cstorlazzi@usgs.gov

\section{Appendix. Acoustic Doppler Current Profiler (ADCP) Information}

Nortek Instruments 2-MHz Aquadopp upward-looking acoustic Doppler current profiler $\mathrm{s} / \mathrm{n}$ :

1757

Transmitting frequency: $\quad 2 \mathrm{MHz}$

Depth of transducer: $\quad 1.7 \mathrm{~m}$

Blanking distance: $\quad 0.20 \mathrm{~m}$

Height of first bin above bed: $\quad 0.50 \mathrm{~m}$

Bin size: $\quad 0.25 \mathrm{~m}$

Number of bins: $\quad 10$

Average interval: $\quad$ 0:08:00.00 
Profile interval:

Wave interval:

Wave cell size:

Operating mode:

Sound speed calculation:
0:15:00.00

1:00:00.00

$0.5 \mathrm{~m}$

High-resolution

Set salinity, updating temperature via sensor

Data Processing:

The Nortek current data were processed using the Prof2NDP program and the wave data using the QuickWave program.

The data were averaged over 1 hour ensembles, all of the spurious data above the water surface were removed, and all of the data in bins where the beam correlation dropped below 80 percent were removed for visualization and analysis.

\section{Tables}

Table 1. Experiment personnel.

[USGS, U.S. Geological Survey; UA, University of Alabama; UH, University of Hawaii]

\begin{tabular}{|l|c|l|}
\hline Person & Affiliation & Responsibilities \\
\hline Peter Swarzenski & USGS & Chief Scientist, oceanographer \\
Curt Storlazzi & USGS & Chief Scientist, oceanographer \\
Kathy Presto & USGS & Oceanographer \\
Ann Gibbs & USGS & Geologist \\
Chris Smith & USGS & Geologist \\
Natasha Dimova & UA & Geochemist \\
Megan Dailer & UH & Biologist \\
Josh Logan & USGS & Physical scientist \\
\hline
\end{tabular}

Table 2. Experiment location information.

[ADCP, Acoustic Doppler current profiler]

\begin{tabular}{|l|c|c|}
\hline Site Name & $\begin{array}{c}\text { Latitude } \\
\text { (decimal degrees) }\end{array}$ & $\begin{array}{c}\text { Longitude } \\
\text { (decimal degrees) }\end{array}$ \\
\hline ADCP & 20.938631 & -156.693122 \\
Vent site-mooring & 20.938576 & -156.693612 \\
Resistivity line A (start) & 20.935763 & -156.692697 \\
Resistivity line A (end) & 20.934664 & -156.692737 \\
Resistivity line B (start) & 20.93897 & -156.69270 \\
Resistivity line B (end) & 20.93799 & -156.69281 \\
Resistivity line C (start) & 20.94471 & -156.69234 \\
Resistivity line C (end) & 20.94569 & -156.69229 \\
Site A-mooring & 20.934477 & -156.693612 \\
Site B-mooring & 20.938499 & -156.694476 \\
Site C-mooring & 20.944505 & -156.693707 \\
\hline
\end{tabular}


Table 3. Select trace-element concentrations in surface water at the primary vent site at Kahekili Beach Park.

[Molybdenum (Mo), barium (Ba), rhenium (Re), vanadium (V), iron (Fe), cesium (Cs), uranium (U), chromium $(\mathrm{Cr})$, and manganese $(\mathrm{Mn})$ in $\mathrm{nM}$, nanomolar]

\begin{tabular}{|l|r|r|r|r|r|r|r|r|r|}
\hline Sample ID & $\begin{array}{c}\text { Mo } \\
\text { [nM] }\end{array}$ & $\begin{array}{c}\mathrm{Ba} \\
\text { [nM] }\end{array}$ & $\begin{array}{c}\mathrm{Re} \\
{[\mathrm{nM}]}\end{array}$ & $\begin{array}{c}\mathrm{V} \\
\mathrm{nM}]\end{array}$ & $\begin{array}{c}\mathrm{Fe} \\
{[\mathrm{nM}]}\end{array}$ & $\begin{array}{c}\mathrm{Cs} \\
{[\mathrm{nM}]}\end{array}$ & $\begin{array}{c}\mathrm{U} \\
{[\mathrm{nM}]}\end{array}$ & $\begin{array}{c}\mathrm{Cr} \\
{[\mathrm{nM}]}\end{array}$ & $\begin{array}{c}\mathrm{Mn} \\
{[\mathrm{nM}]}\end{array}$ \\
\hline T1-800-SW & 98 & 29 & 0.044 & 32 & 97 & 1.80 & 10.34 & 3.6 & 7 \\
T2-900-SW & 108 & 30 & 0.053 & 36 & 66 & 2.02 & 11.41 & 3.0 & 7 \\
T3-1000-SW (low tide) & 105 & 30 & 0.039 & 37 & 226 & 1.92 & 11.28 & 11.1 & 58 \\
T4-1100-SW & 107 & 30 & 0.046 & 39 & 261 & 1.92 & 11.31 & 13.2 & 8 \\
T5-1200-SW & 110 & 30 & 0.043 & 51 & 3,859 & 1.94 & 11.10 & 177.7 & 148 \\
T6-1300-SW & 106 & 30 & 0.036 & 46 & 2,719 & 1.85 & 10.67 & 121.8 & 320 \\
T7-1400-SW & 106 & 30 & 0.039 & 44 & 2,923 & 1.87 & 10.83 & 127.3 & 128 \\
T8-1500-SW & 108 & 30 & 0.050 & 42 & 2,066 & 1.93 & 11.17 & 89.0 & 194 \\
T9-1600-SW & 105 & 30 & 0.041 & 33 & 812 & 1.91 & 10.93 & 19.4 & 98 \\
T10-1700-SW & 105 & 30 & 0.041 & 35 & 847 & 1.89 & 11.02 & 23.8 & 72 \\
T11-1800-SW (high tide) & 108 & 30 & 0.038 & 36 & 2,543 & 1.91 & 11.20 & 65.6 & 196 \\
\hline
\end{tabular}

Table 4. Select trace-element concentrations in discharging vent water at the primary vent site at Kahekili Beach Park.

[Molybdenum (Mo), barium (Ba), rhenium $(\mathrm{Re})$, vanadium $(\mathrm{V})$, iron $(\mathrm{Fe})$, cesium $(\mathrm{Cs})$, uranium $(\mathrm{U})$, chromium $(\mathrm{Cr})$, and manganese $(\mathrm{Mn})$ in $\mathrm{nM}$, nanomolar]

\begin{tabular}{|l|r|r|r|r|r|r|r|r|r|}
\hline Sample ID & $\begin{array}{c}\mathrm{Mo} \\
\mathrm{nM}]\end{array}$ & $\begin{array}{c}\mathrm{Ba} \\
\mathrm{nM}]\end{array}$ & $\begin{array}{c}\mathrm{Re} \\
{[\mathrm{nM}]}\end{array}$ & $\begin{array}{c}\mathrm{V} \\
{[\mathrm{nM}]}\end{array}$ & $\begin{array}{c}\mathrm{Fe} \\
{[\mathrm{nM}]}\end{array}$ & $\begin{array}{c}\mathrm{Cs} \\
{[\mathrm{nM}]}\end{array}$ & $\begin{array}{c}\mathrm{U} \\
{[\mathrm{nM}]}\end{array}$ & $\begin{array}{c}\mathrm{Cr} \\
{[\mathrm{nM}]}\end{array}$ & $\begin{array}{c}\mathrm{Mn} \\
{[\mathrm{nM}]}\end{array}$ \\
\hline T1-800-GW & 30 & 11 & 0.002 & 200 & 44 & 0.48 & 0.50 & 1.3 & 8,355 \\
T2-900-GW & 51 & 21 & 0.005 & 330 & 71 & 0.87 & 1.05 & 1.9 & 13,884 \\
T3-1000-GW (low tide) & 42 & 16 & 0.002 & 273 & 154 & 0.70 & 0.65 & 6.9 & 11,933 \\
T4-1100-GW & 54 & 19 & 0.005 & 348 & 3145 & 0.82 & 0.78 & 133.3 & 14,500 \\
T5-1200-GW & 41 & 15 & 0.002 & 269 & 2090 & 0.64 & 0.60 & 92.8 & 11,343 \\
T6-1300-GW & 43 & 16 & 0.003 & 276 & 2316 & 0.66 & 0.62 & 98.1 & 11,421 \\
T7-1400-GW & 38 & 13 & 0.002 & 240 & 2518 & 0.58 & 0.56 & 104.8 & 10,185 \\
T8-1500-GW & 51 & 19 & 0.005 & 337 & 2398 & 0.82 & 0.81 & 95.0 & 14,400 \\
T9-1600-GW & 51 & 21 & 0.004 & 321 & $\mathrm{n} / \mathrm{a}$ & 0.86 & 1.06 & $\mathrm{n} / \mathrm{a}$ & 14,257 \\
T10-1700-GW & 43 & 14 & 0.005 & 273 & 3244 & 0.65 & 0.74 & 87.4 & 10,589 \\
T11-1800-GW (high tide) & 53 & 22 & 0.004 & 309 & 6976 & 0.84 & 1.23 & 204.2 & 13,046 \\
\hline
\end{tabular}

Table 5. Nutrient concentrations in surface water at the primary vent site at Kahekili Beach Park.

[All samples unacidified unless denoted. Ammonium $\left(\mathrm{NH}_{4}{ }^{+}\right)$, dissolved silicate (DSi), soluble reactive phosphorus (SRP), nitrate-nitrite $\left(\mathrm{NO}_{3}{ }^{-}+\mathrm{NO}_{2}{ }^{-}\right.$), dissolved inorganic nitrogen, (DIN), dissolved organic nitrogen (DON), total dissolve nitrogen (TDN), and total dissolved phosphorus (TDP). $\mu \mathrm{M}$, micromolar]

\begin{tabular}{|l|c|r|r|r|r|r|r|r|}
\hline Sample ID & $\begin{array}{c}\mathrm{NH}_{4} \\
{[\mu \mathrm{M}]}\end{array}$ & \multicolumn{1}{c|}{$\begin{array}{c}\mathrm{DSi} \\
{[\mu \mathrm{M}]}\end{array}$} & $\begin{array}{c}\mathrm{SRP} \\
{[\mu \mathrm{M}]}\end{array}$ & $\begin{array}{c}\left.\mathrm{NO}_{3}{ }^{-}+\mathrm{NO}_{2}{ }^{-}\right] \\
{[\mu \mathrm{M}]}\end{array}$ & $\begin{array}{c}\mathrm{DIN} \\
{[\mu \mathrm{M}]}\end{array}$ & $\begin{array}{c}\mathrm{DON} \\
{[\mu \mathrm{M}]}\end{array}$ & $\begin{array}{c}\text { TDN } \\
{[\mu \mathrm{M}]}\end{array}$ & $\begin{array}{c}\mathrm{TDP} \\
{[\mu \mathrm{M}]}\end{array}$ \\
\hline T1-800-SW & $<0.05$ & 12.6 & $<0.05$ & 0.1 & 0.1 & 5.7 & 5.8 & 0.1 \\
T2-900-SW & $<0.05$ & 12.0 & $<0.05$ & 0.0 & 0.0 & 5.7 & 5.7 & $<0.05$ \\
T3-1000-SW (low tide) & $<0.05$ & 14.9 & $<0.05$ & 0.3 & 0.3 & 7.2 & 7.4 & 0.1 \\
T4-1100-SW & $<0.05$ & 15.6 & $<0.05$ & 0.1 & 0.1 & 6.4 & 6.5 & 0.1 \\
T5-1200-SW & $<0.05$ & 24.2 & $<0.05$ & 0.4 & 0.4 & 6.2 & 6.6 & 0.2 \\
T6-1300-SW & $<0.05$ & 25.4 & 0.06 & 0.4 & 0.4 & 6.6 & 7.0 & 0.2 \\
T7-1400-SW & $<0.05$ & 24.8 & 0.05 & 0.3 & 0.3 & 6.1 & 6.5 & 0.1 \\
T8-1500-SW & $<0.05$ & 9.5 & $<0.05$ & 0.0 & 0.0 & 6.4 & 6.4 & 0.1 \\
T9-1600-SW & 0.1 & 10.6 & $<0.05$ & $<0.05$ & 0.1 & 5.7 & 5.7 & 0.1 \\
T10-1700-SW & $<0.05$ & 13.9 & 0.04 & 0.2 & 0.2 & 9.3 & 9.5 & 0.1 \\
T11-1800-SW (high tide) & $<0.05$ & 12.2 & $<0.05$ & 0.1 & 0.1 & 8.5 & 8.7 & 0.1 \\
\hline
\end{tabular}


Table 6. Nutrient concentrations in discharging vent water at the primary vent site at Kahekili Beach Park. [All samples unacidified unless denoted. Ammonium $\left(\mathrm{NH}_{4}{ }^{+}\right)$, dissolved silicate (DSi), soluble reactive phosphorus (SRP), nitrate-nitrite $\left(\mathrm{NO}_{3}{ }^{-}+\mathrm{NO}_{2}{ }^{-}\right.$), dissolved inorganic nitrogen, (DIN), dissolved organic nitrogen (DON), total dissolve nitrogen (TDN), and total dissolved phosphorus (TDP). $\mu \mathrm{M}$, micromolar; $\mathrm{n} / \mathrm{a}$, not applicable]

\begin{tabular}{|l|r|r|r|r|r|r|r|r|}
\hline Sample ID & $\begin{array}{c}\mathrm{NH}_{4} \\
{[\mu \mathrm{M}]}\end{array}$ & $\begin{array}{c}\mathrm{DSi} \\
{[\mu \mathrm{M}]}\end{array}$ & $\begin{array}{c}\mathrm{SRP} \\
{[\mu \mathrm{M}]}\end{array}$ & $\begin{array}{r}{\left[\mathrm{NO}_{3}{ }^{-}+\mathrm{NO}_{2}{ }^{-}\right]} \\
{[\mu \mathrm{M}]}\end{array}$ & $\begin{array}{r}\mathrm{DIN} \\
{[\mu \mathrm{M}]}\end{array}$ & $\begin{array}{r}\mathrm{DON} \\
{[\mu \mathrm{M}]}\end{array}$ & $\begin{array}{r}\text { TDN } \\
{[\mu \mathrm{M}]}\end{array}$ & $\begin{array}{r}\mathrm{TDP} \\
{[\mu \mathrm{M}]}\end{array}$ \\
\hline T1-800-GW & 0.3 & 104.3 & 6.03 & 10.5 & 10.8 & 11.2 & 22.0 & 10.2 \\
T2-900-GW & 0.1 & 608.2 & 12.78 & 38.4 & 38.4 & 10.5 & 48.9 & 12.3 \\
T3-1000-GW (low tide) & 0.1 & 775.7 & 13.52 & 42.0 & 42.0 & 10.8 & 52.8 & 12.2 \\
T4-1100-GW & 0.1 & 790.4 & 13.20 & 42.2 & 42.3 & 9.9 & 52.1 & 12.4 \\
T5-1200-GW & 0.1 & 581.8 & $\mathrm{n} / \mathrm{a}$ & $\mathrm{n} / \mathrm{a}$ & $\mathrm{n} / \mathrm{a}$ & $\mathrm{n} / \mathrm{a}$ & $\mathrm{n} / \mathrm{a}$ & $\mathrm{n} / \mathrm{a}$ \\
T6-1300-GW & 0.1 & 431.9 & 13.62 & 42.0 & 42.1 & 10.4 & 52.5 & 11.0 \\
T7-1400-GW & 0.1 & 620.0 & 13.52 & 41.8 & 41.8 & 12.8 & 54.7 & 12.5 \\
T8-1500-GW & 0.0 & 813.9 & 13.41 & 41.6 & 41.6 & 11.2 & 52.8 & 12.1 \\
T9-1600-GW & 0.2 & 587.6 & 13.41 & 41.6 & 41.7 & 9.4 & 51.2 & 13.0 \\
T10-1700-GW & 0.1 & 455.4 & 13.09 & 41.2 & 41.4 & 8.8 & 50.2 & 11.5 \\
T11-1800-GW (high tide) & 2.2 & 649.3 & 8.22 & 26.2 & 28.4 & 2.5 & 30.9 & 13.0 \\
\hline
\end{tabular}

Table 7. Wave statistics at the Acoustic Doppler current profiler (ADCP) site.

[m, meter; s, second; ${ }^{\circ}$, degrees true north]

\begin{tabular}{|l|c|c|c|c|}
\hline Site Name & Parameter & Mean \pm 1 Std Deviation & Minimum & Maximum \\
\hline ADCP & Height [m] & $0.5 \pm 0.12$ & 0.31 & 0.78 \\
& Period [s] & $8.2 \pm 1.6$ & 4.2 & 11.0 \\
& Direction [ $\left.{ }^{\circ}\right]$ & $53.9 \pm 34.0$ & 45.9 & 83.6 \\
\hline
\end{tabular}

Table 8. Current and temperature statistics at the Acoustic Doppler current profiler (ADCP) site.

[m, meter; s, second; o, degrees true north; N.S., near surface; N.B., near seabed]

\begin{tabular}{|l|c|c|c|c|c|}
\hline Site Name & Parameter & Depth [m] & Mean \pm 1 Std Deviation & Minimum & Maximum \\
\hline ADCP & Speed [m/s] & [N.S.] & $0.05 \pm 0.02$ & 0.01 & 0.11 \\
& Direction [ ${ }^{\circ}$ ] & [N.S.] & $260.0 \pm 20.9$ & 0.0 & 359.9 \\
& Speed [m/s] & [N.B.] & $0.04 \pm 0.02$ & 0.00 & 0.09 \\
& Direction [ [ $]$ & [N.B.] & $234.1 \pm 26.7$ & 0.0 & 359.9 \\
& Temperature [ ${ }^{\circ}$ C] & [N.B.] & $21.28 \pm 0.38$ & 20.62 & 22.24 \\
\hline
\end{tabular}

Table 9. Mean radon-222 ( $\left.{ }^{222} \mathrm{Rn}\right)$ derived submarine groundwater discharge (SGD) rates at the four timeseries moorings at Kahekili Beach Park.

[cm/d, centimeters per day]

\begin{tabular}{|l|c|}
\hline Site ID & $\begin{array}{c}\text { SGD rate } \\
{[\mathrm{cm} / \mathrm{d}]}\end{array}$ \\
\hline Vent site & 55 \\
Site A & 21 \\
Site B & 30 \\
Site C & 22 \\
\hline
\end{tabular}


Table 10. Mean discharging groundwater nutrient concentrations in select coastal groundwater systems in Hawaii.

[Ammonium $\left(\mathrm{NH}_{4}{ }^{+}\right)$, dissolved silicate (DSi), soluble reactive phosphorus (SRP), nitrate-nitrite $\left(\mathrm{NO}_{3}{ }^{-}+\mathrm{NO}_{2}{ }^{-}\right.$), dissolved inorganic nitrogen, (DIN), dissolved organic nitrogen (DON), total dissolve nitrogen (TDN), and total dissolved phosphorus (TDP). $\mu \mathrm{M}$, micromolar]

\begin{tabular}{|l|r|r|r|r|r|r|r|r|}
\hline Sample ID & $\begin{array}{c}\mathrm{NH}_{4} \\
{[\mu \mathrm{M}]}\end{array}$ & $\begin{array}{c}\mathrm{DSi} \\
{[\mu \mathrm{M}]}\end{array}$ & $\begin{array}{l}\mathrm{SRP} \\
{[\mu \mathrm{M}]}\end{array}$ & $\begin{array}{c}{\left[\mathrm{NO}_{2}+\mathrm{NO}_{3}\right]} \\
{[\mu \mathrm{M}]}\end{array}$ & $\begin{array}{c}\text { DIN } \\
{[\mu \mathrm{M}]}\end{array}$ & $\begin{array}{c}\text { DON } \\
{[\mu \mathrm{M}]}\end{array}$ & $\begin{array}{c}\text { TDN } \\
{[\mu \mathrm{M}]}\end{array}$ & $\begin{array}{c}\text { TDP } \\
{[\mu \mathrm{M}]}\end{array}$ \\
\hline Kahekili, Maui & 0.3 & 583.5 & 12.8 & 39.6 & 40.0 & 9.7 & 49.5 & 12.2 \\
Black Point, Oahu & 1.2 & 210.8 & 2.6 & 141.9 & 143.1 & 10.3 & 153.4 & 2.8 \\
Niu, Oahu & 0.3 & 234.4 & 1.2 & 47.1 & 47.4 & 4.2 & 51.6 & 1.7 \\
\hline
\end{tabular}

Table 11. Loading estimates per meter of shoreline of nutrient concentrations from select nearshore sites in Hawaii.

[Ammonium $\left(\mathrm{NH}_{4}{ }^{+}\right)$, dissolved silicate (DSi), soluble reactive phosphorus (SRP), nitrate-nitrite $\left(\mathrm{NO}_{3}{ }^{-}+\mathrm{NO}_{2}{ }^{-}\right.$), dissolved inorganic nitrogen, (DIN), dissolved organic nitrogen (DON), total dissolve nitrogen (TDN), and total dissolved phosphorus (TDP). Mol/d/m, moles per day per meter]

\begin{tabular}{|l|r|r|r|r|r|r|r|r|}
\hline ID & $\begin{array}{c}\mathrm{NH}_{4} \\
{[\mathrm{~mol} / \mathrm{d} / \mathrm{m}]}\end{array}$ & $\begin{array}{c}\text { DSi } \\
{[\mathrm{mol} / \mathrm{d} / \mathrm{m}]}\end{array}$ & $\begin{array}{c}\text { SRP } \\
{[\mathrm{mol} / \mathrm{d} / \mathrm{m}]}\end{array}$ & $\begin{array}{c}{\left[\mathrm{NO}_{3}{ }^{-}+\mathrm{NO}_{2}{ }^{-}\right]} \\
{[\mathrm{mol} / \mathrm{d} / \mathrm{m}]}\end{array}$ & $\begin{array}{c}\text { DIN } \\
{[\mathrm{mol} / \mathrm{d} / \mathrm{m}]}\end{array}$ & $\begin{array}{c}\text { DON } \\
{[\mathrm{mol} / \mathrm{d} /} \\
\mathrm{m}]\end{array}$ & $\begin{array}{c}\text { TDN } \\
{[\mathrm{mol} / \mathrm{d} / \mathrm{m}]}\end{array}$ & $\begin{array}{c}\text { TDP } \\
{[\mathrm{mol} / \mathrm{d} / \mathrm{m}]}\end{array}$ \\
\hline Kahekili, Maui & 0.02 & 32.09 & 0.70 & 2.18 & 2.20 & 0.54 & 2.73 & 0.67 \\
Black Point, & 0.04 & 6.98 & 0.09 & 4.70 & 4.74 & 0.34 & 5.08 & 0.09 \\
Oahu & & & & & & & \\
Niu, Oahu & 0.01 & 6.98 & 0.04 & 1.40 & 1.41 & 0.13 & 1.54 & 0.05 \\
\hline
\end{tabular}




\section{Figures}

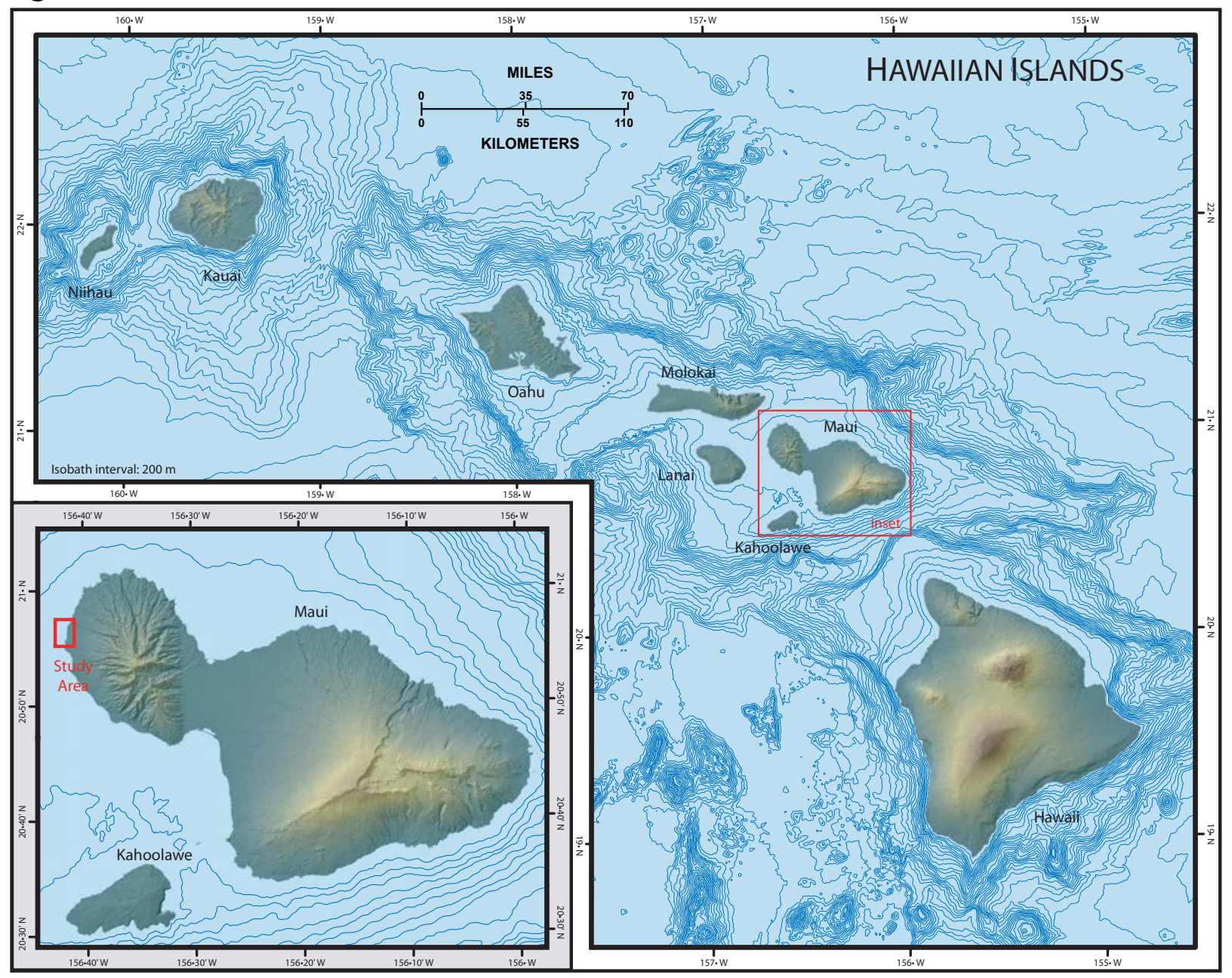

Figure 1. Map depicting Maui, Hawaii, and surrounding islands. Study site is located on the northwest coast of Maui. 


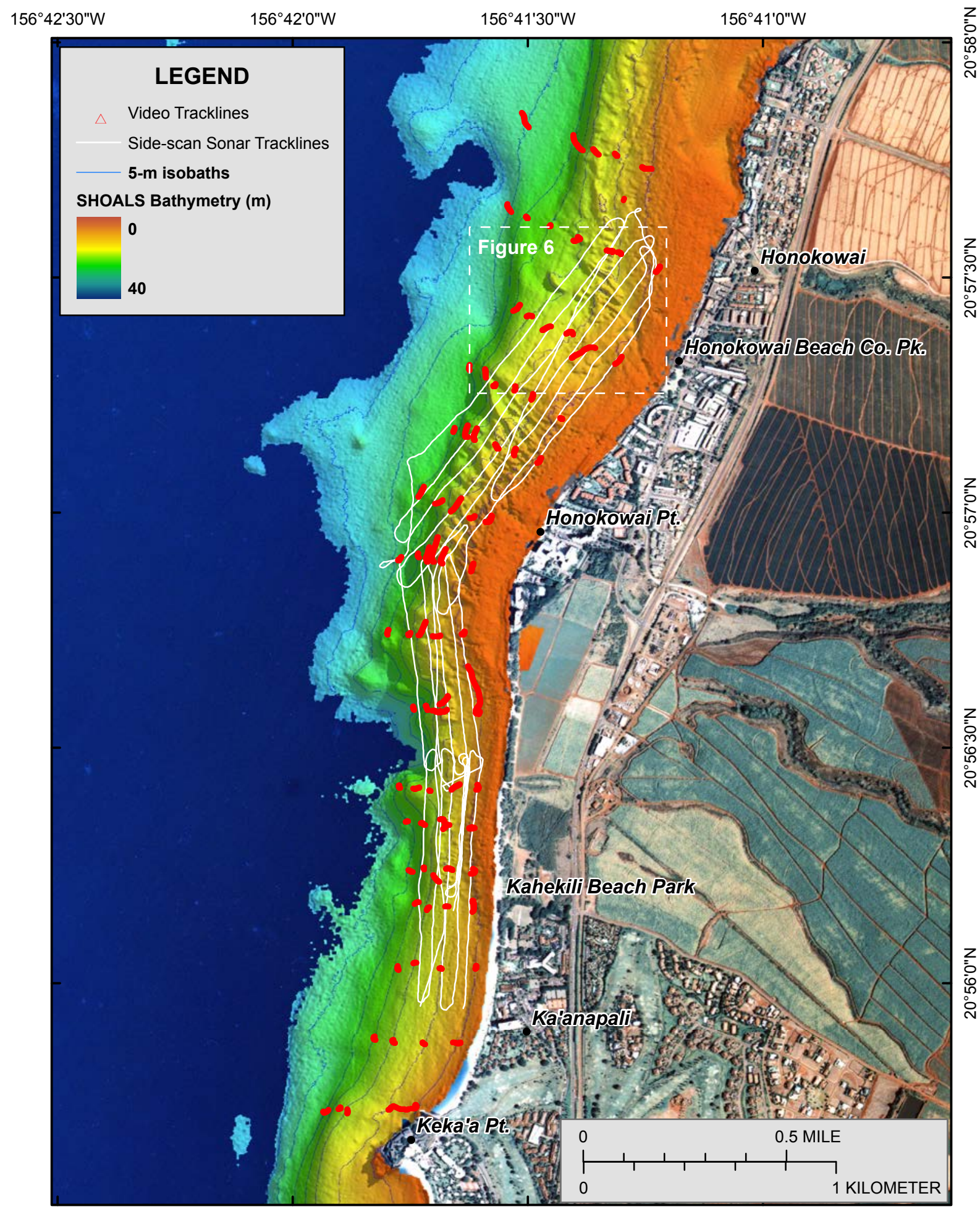

Figure 2. Aerial photograph and SHOALS (Scanning Hydrographic Operational Airborne Lidar Survey) lidar bathymetric map of the west Maui study area showing the video and side-scan sonar tracklines. Side-scan sonar tracklines were collected parallel to shore from Kaanapali to Honokowai. The video tracklines were completed from as close as possible to shore to approximately the 25 meter $(\mathrm{m})$ isobath along every 5-m isobath. 


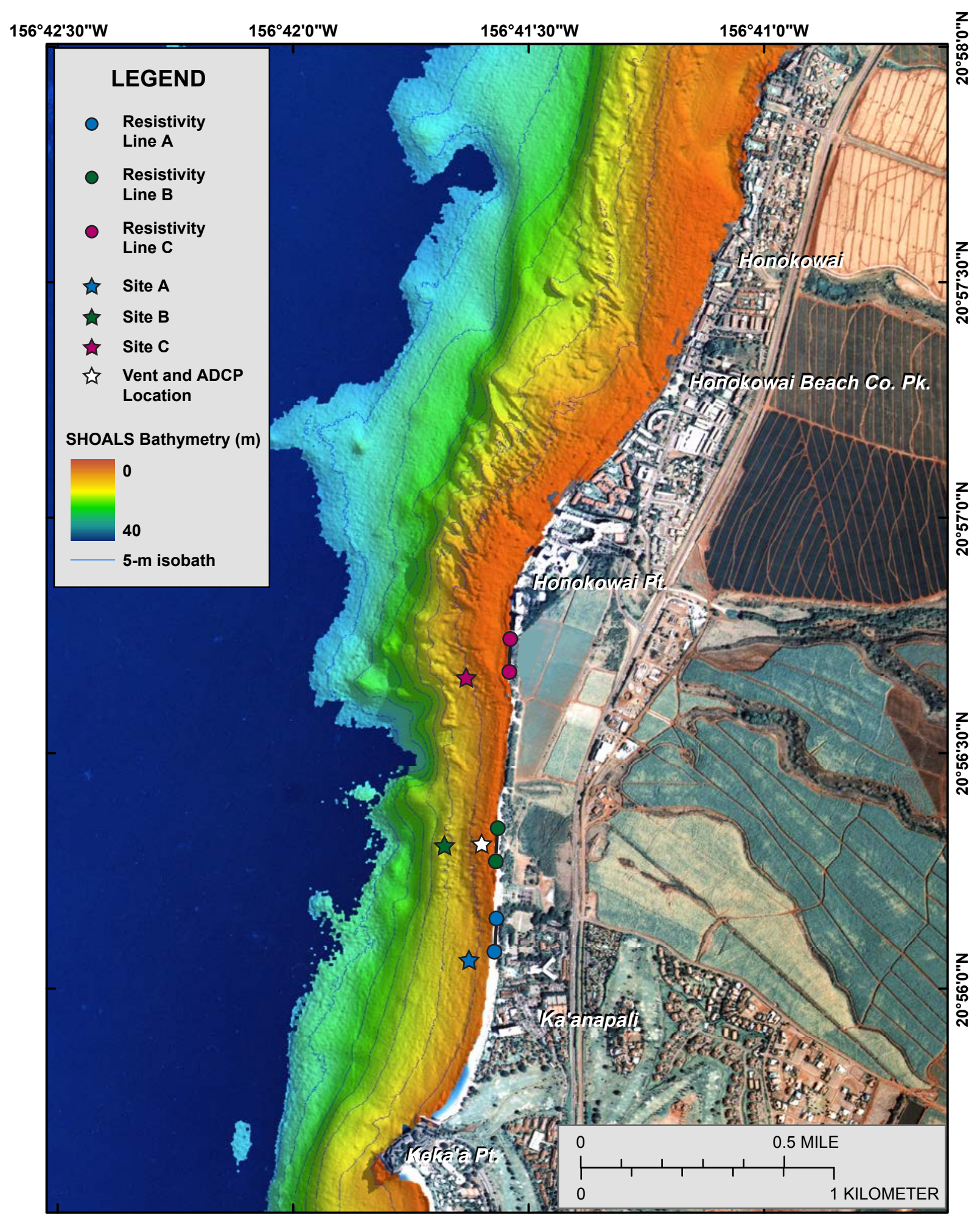

Figure 3. Aerial photograph and SHOALS (Scanning Hydrographic Operational Airborne Lidar Survey) lidar bathymetric map of the west Maui study area showing the location of instruments, resistivity lines, vent sites, and major landmarks. Vent and ADCP, primary submarine groundwater vent and acoustic Doppler current profiler (ADCP); m, meters. 


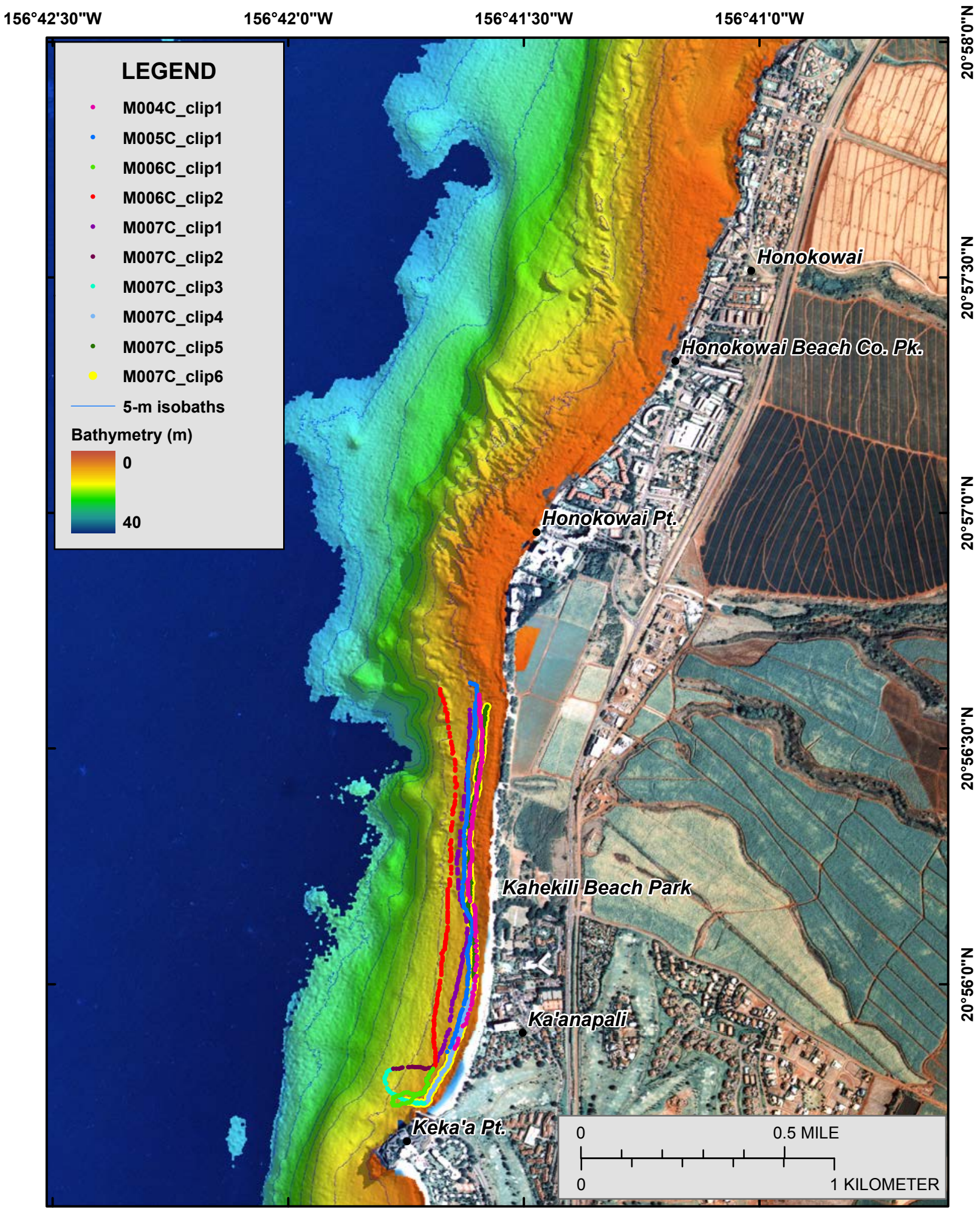

Figure 4. Aerial photograph and SHOALS (Scanning Hydrographic Operational Airborne Lidar Survey) lidar bathymetric map of the west Maui study area showing the location of the continuous resistivity profiling lines. $m$, meter. 


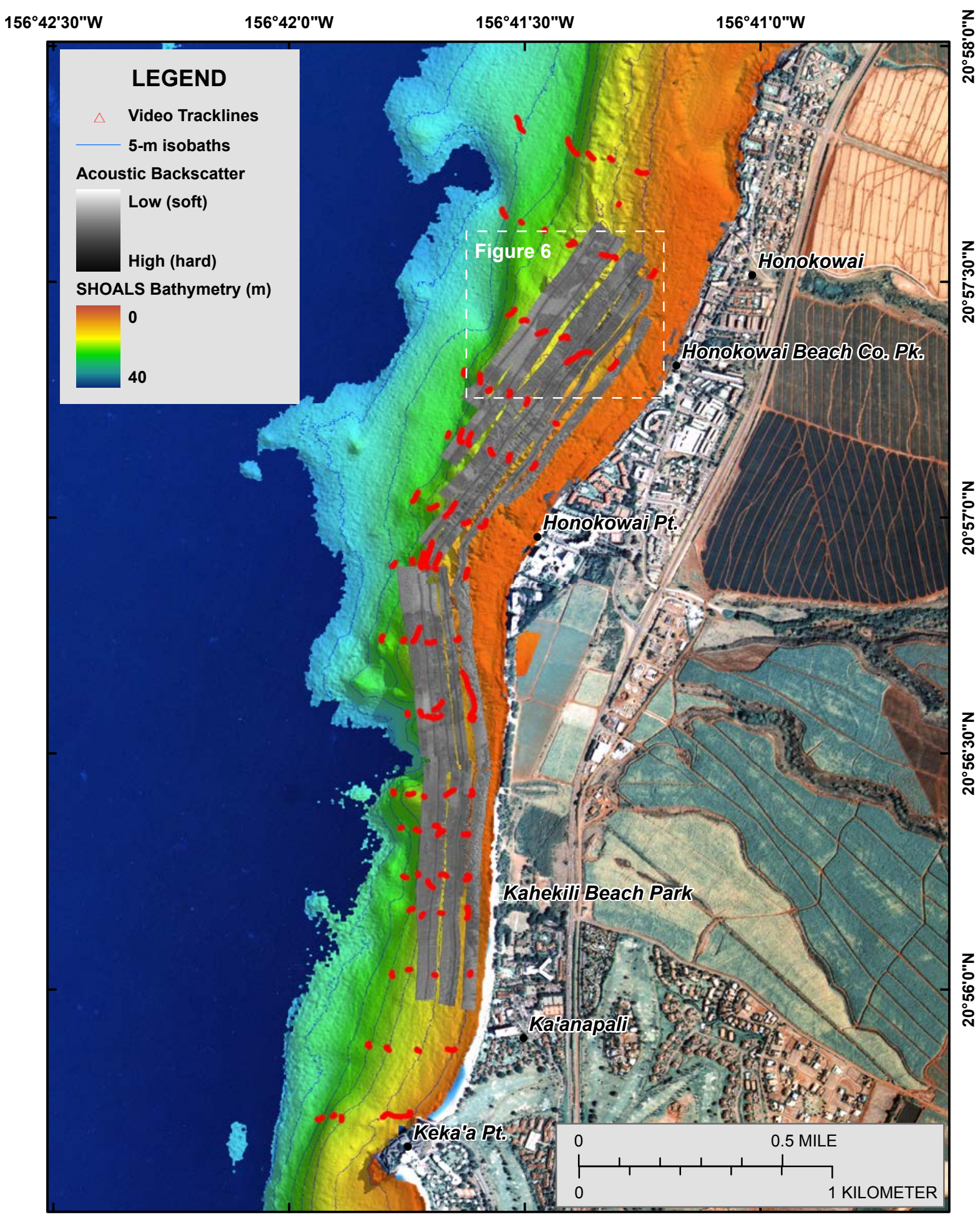

Figure 5. Aerial photograph and SHOALS (Scanning Hydrographic Operational Airborne Lidar Survey) lidar bathymetric map of the west Maui study area overlaid with the side-scan sonar data collected in the study area. The acoustic backscatter shows soft sand as brighter hues and harder rock as dark hues. Inset shows area of figure $6 . \mathrm{m}$, meters. 


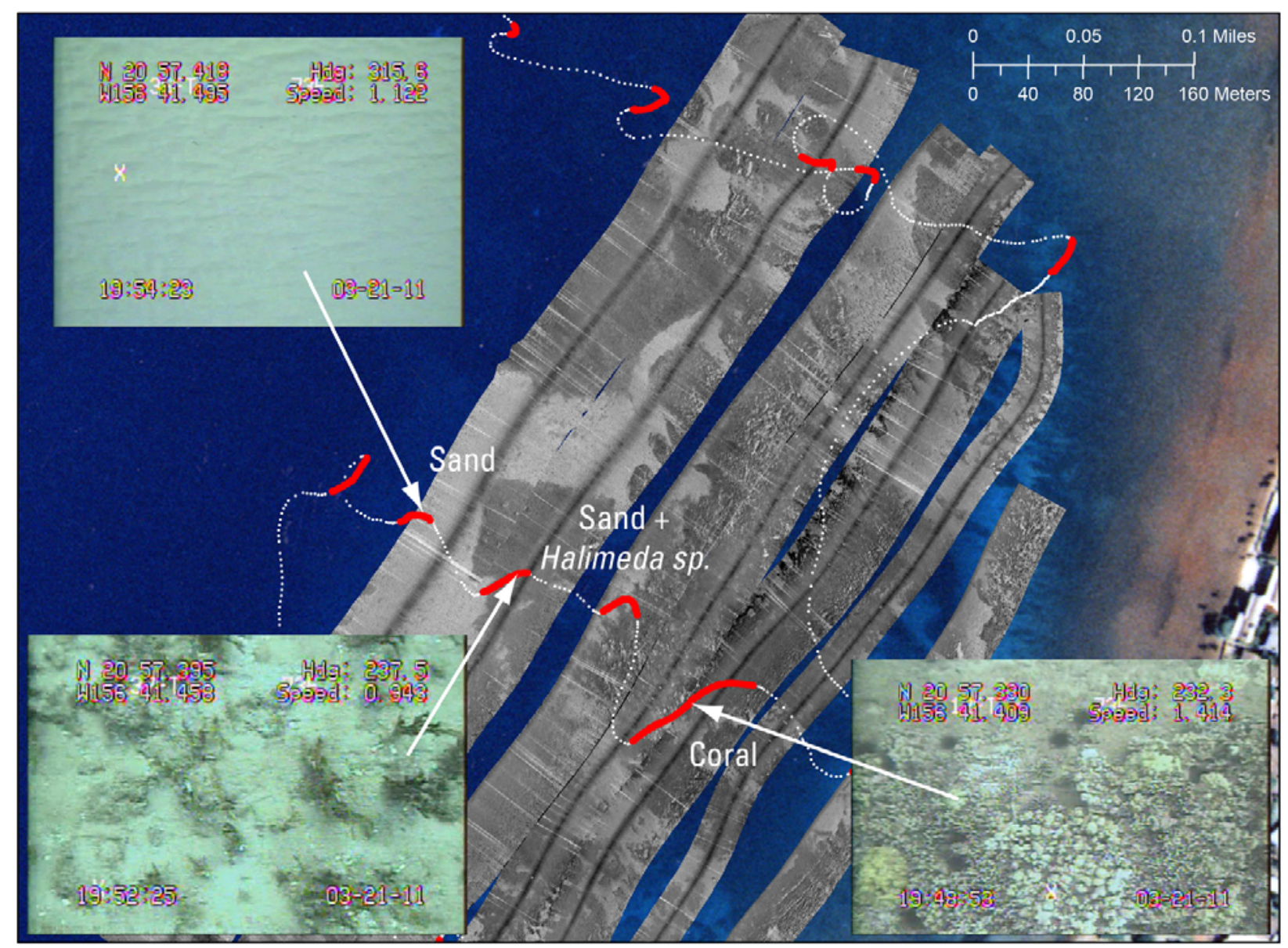

Figure 6. Side-scan sonar map and video images of the seafloor in the northern part of the the west Maui study area. The acoustic backscatter shows soft sand as brighter hues and harder rock as dark hues. Inset photographs showing video confirmation of seafloor habitats at select sites. See figures 2 and 5 for the location of this region in the study area. 


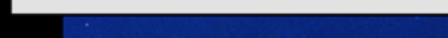

(⿸丆口


$\boldsymbol{A}$

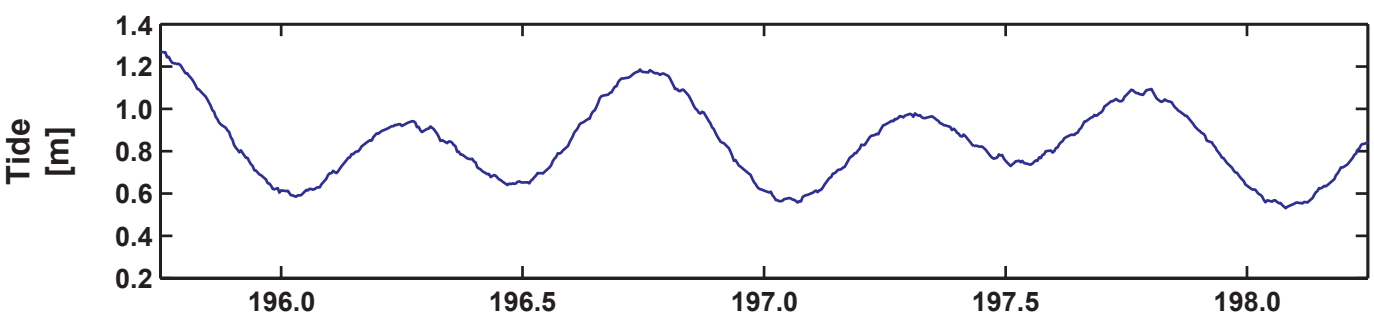

$B$

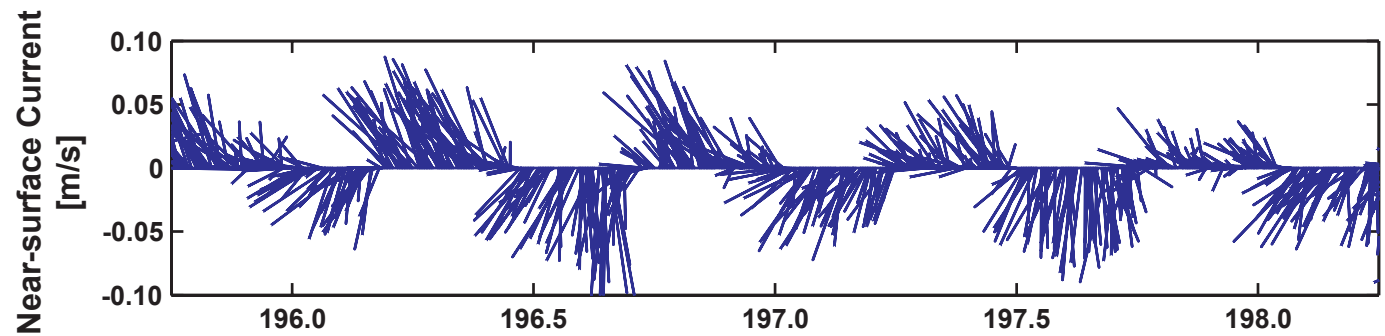

C

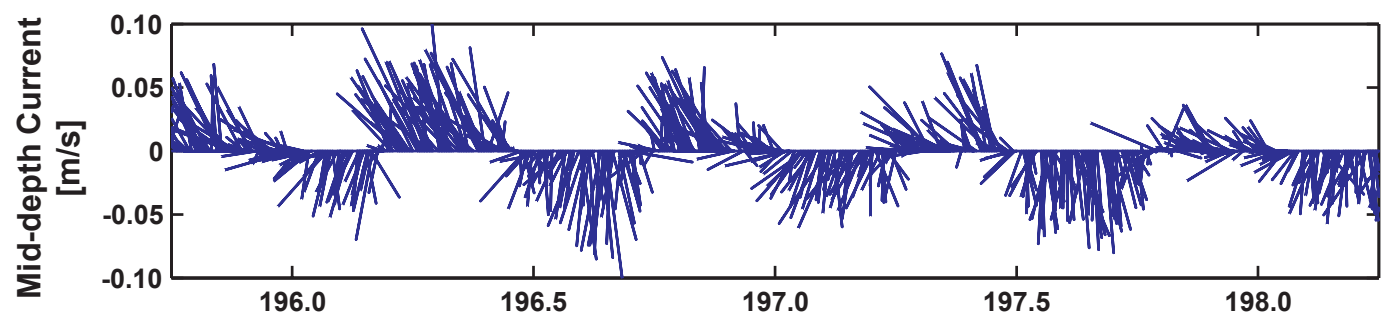

$D$

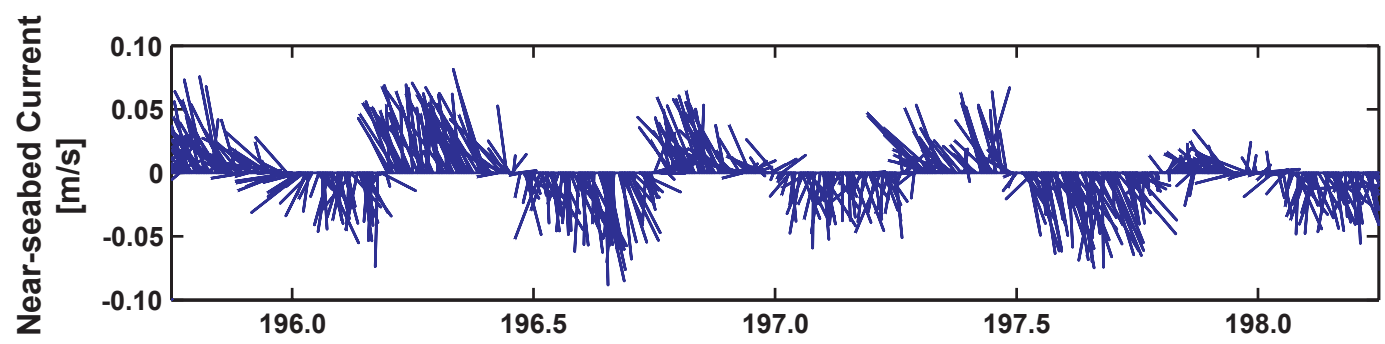

$E$

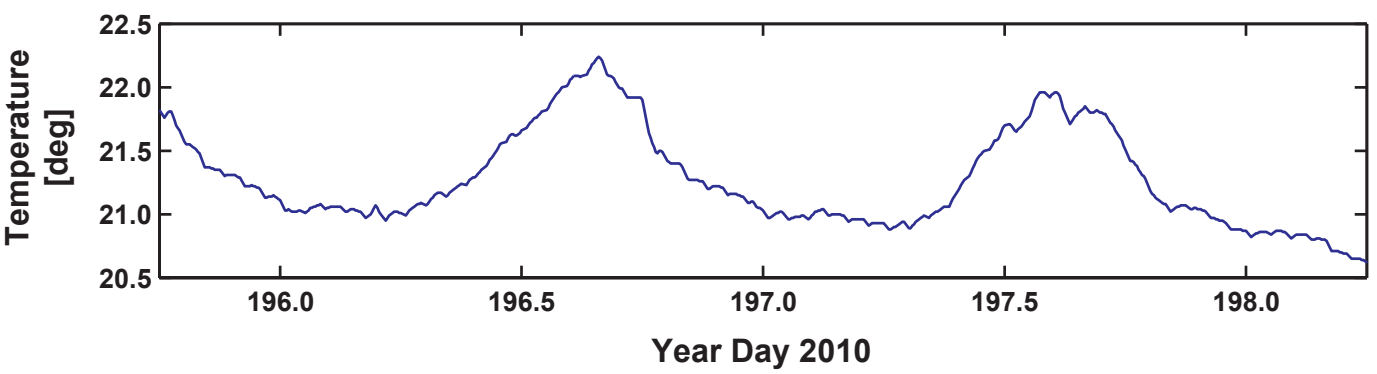

Figure 8. Time-series plots of tide, current, and water temperature data from the Acoustic Doppler current profiler (ADCP) at the primary submarine groundwater vent site. $A$, Tidal height, in meters. $B$, Nearsurface current speeds and directions, in meters per second from true north. $C$, Mid-depth current speeds and directions, in meters per second from true north. $D$, Near-bed current speeds and directions, in meters per second from true north. $E$, Temperature, in degrees Celsius. The 2-day time series shows the currents were fairly uniform throughout the water column and were modulated by the tide. The temperature data showed insolation-driven diurnal heating and cooling at this site. $\mathrm{m}$, meters; $\mathrm{m} / \mathrm{s}$, meters per second; deg, degrees Celsius. 


\section{A}

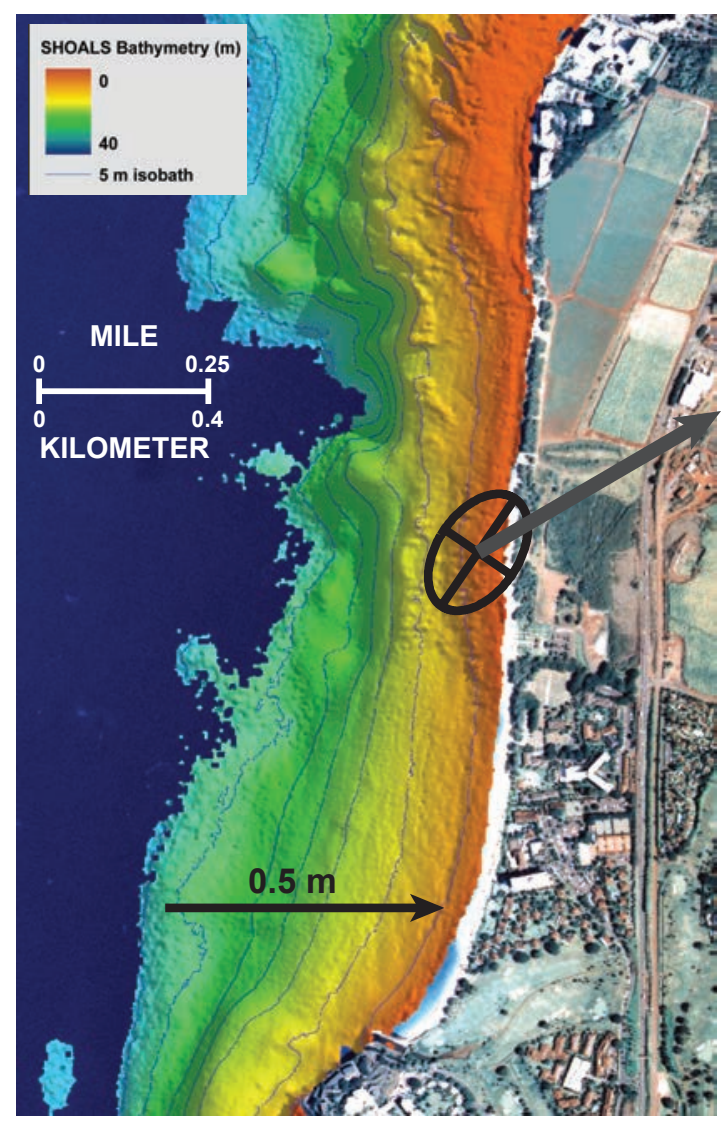

\section{B}

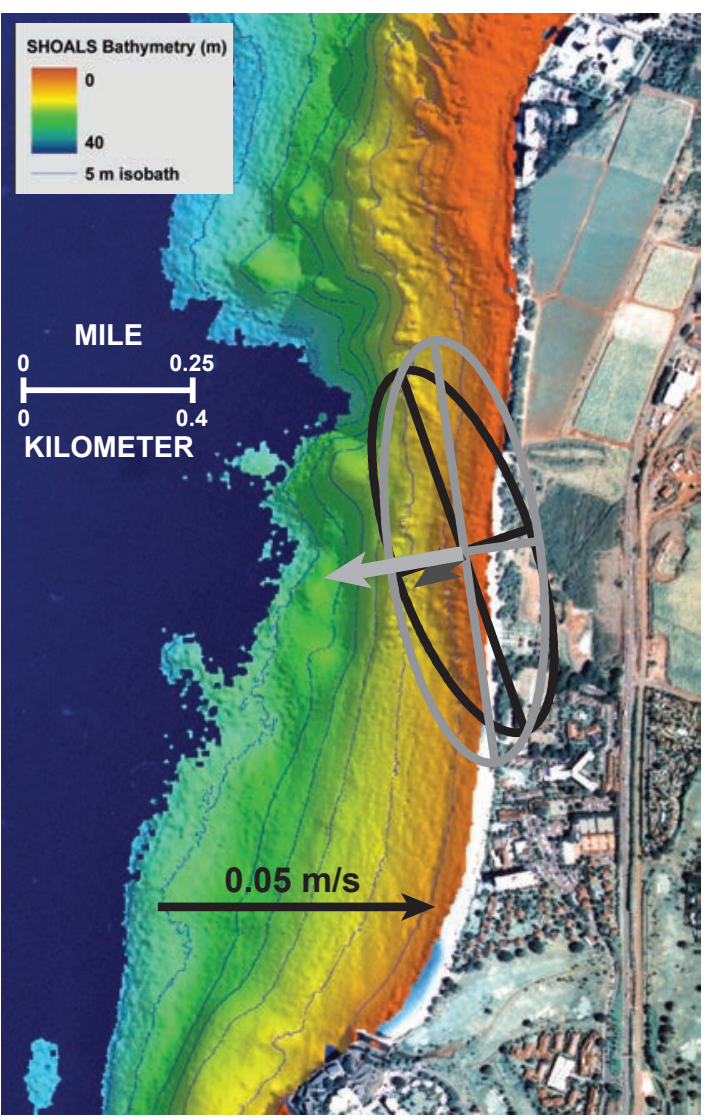

Figure 9. Map showing the mean (vectors) and variability (ellipses) of waves and currents at the primary submarine groundwater vent site . $A$, wave height and direction, in meters from true north. $B$, Nearsurface (grey vector/ellipse) and near-seabed (black vector/ellipse) current speeds (in meters per second, $\mathrm{m} / \mathrm{s}$ ) and directions, in degrees from true north. The mean wave height is approximately 0.5 meters $(\mathrm{m})$ from the southwest and the mean current direction is offshore to the southwest, with faster currents measured near the surface. 
Cumulative Flow: Low Tide to +3 hours

Gray $=$ Near-surface, Black $=$ Near-seabed

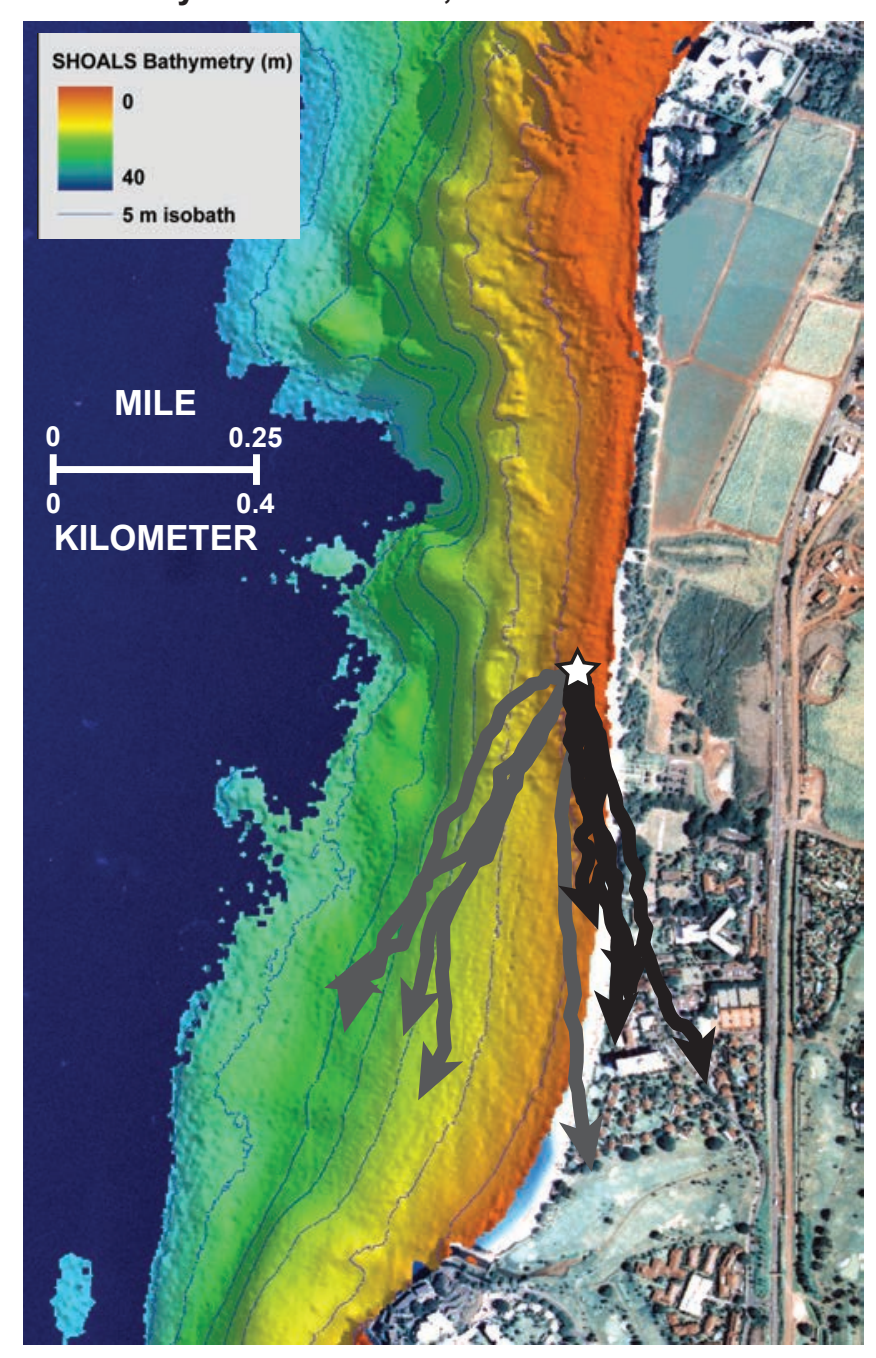

Figure 10. Map showing modeled cumulative flow distance for 3 hours following low tide at the near surface (gray vectors) and near bed (black vectors) at the primary submarine groundwater vent site. Submarine groundwater discharge volumes were highest in the 3 hours following low tide, so these data provide insight into the dominant direction and distance of submarine groundwater transport from the primary vent site off Kahekili. The flow at the near surface was slightly faster and more to the southwest than the flow near the seabed, $m$, meters. 


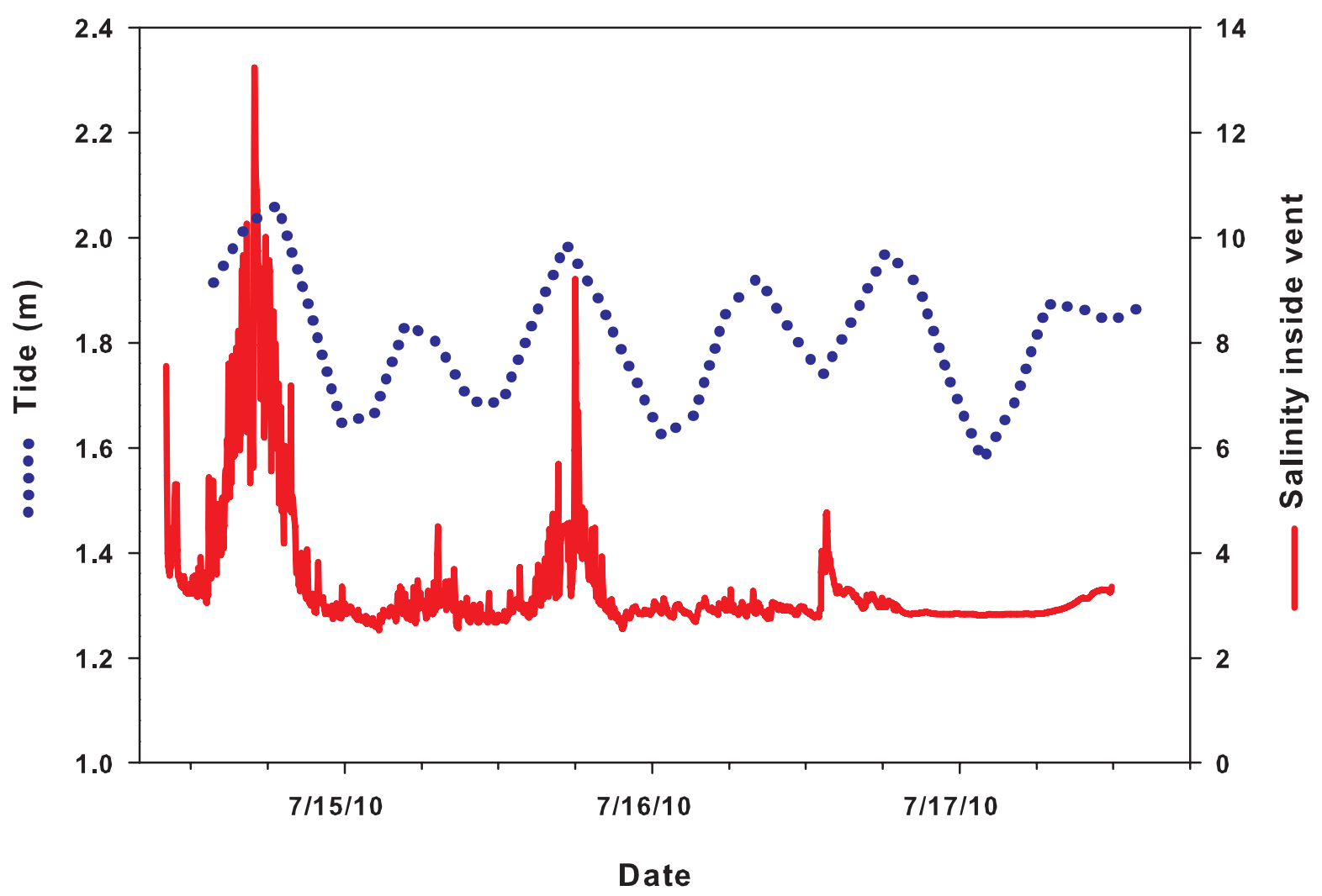

Figure 11. Time-series plots of salinity of the discharging submarine groundwater and tide level (in meters, $\mathrm{m})$ at the primary vent site. 


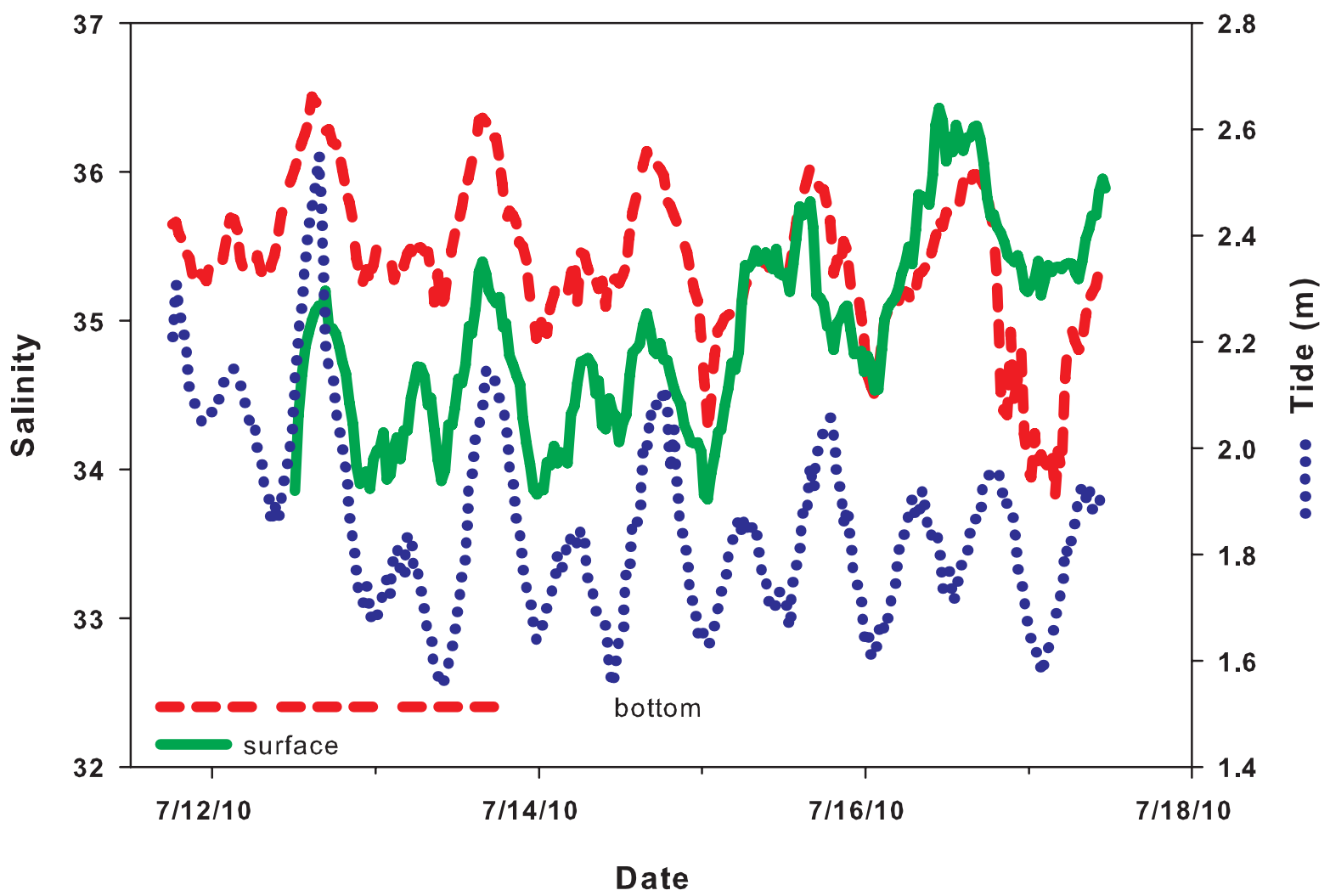

Figure 12. Time-series plots of surface water and bottom water salinity and tide level (in meters, $m$ ) at the primary vent site. 


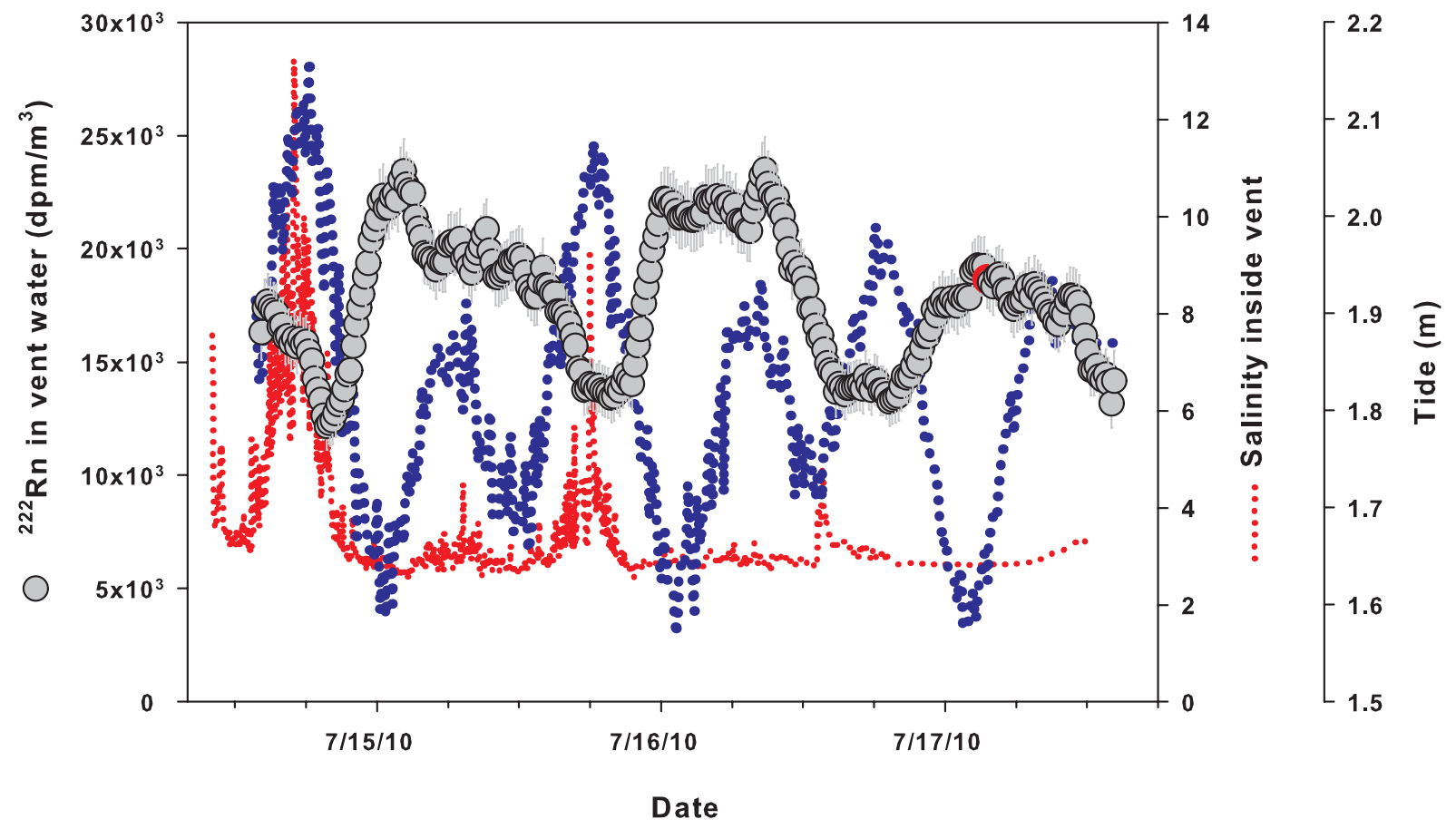

Figure 13. Time-series plots of radon-222 (222Rn) activities, in disintegrations per minute per cubic meter of water $\left(\mathrm{dpm} / \mathrm{m}^{3}\right)$, salinity, and tide level, in meters $(\mathrm{m})$, at the primary submarine groundwater vent site. This groundwater was captured using a piezometer that was inserted into the throat of an active spring vent by a diver using scuba. A representative groundwater end member ${ }^{222} \mathrm{Rn}$ value $\left(27,045 \mathrm{dpm} / \mathrm{m}^{3}\right)$ used in the radon mass balance was extracted from this groundwater ${ }^{222} \mathrm{Rn}$ time series. 


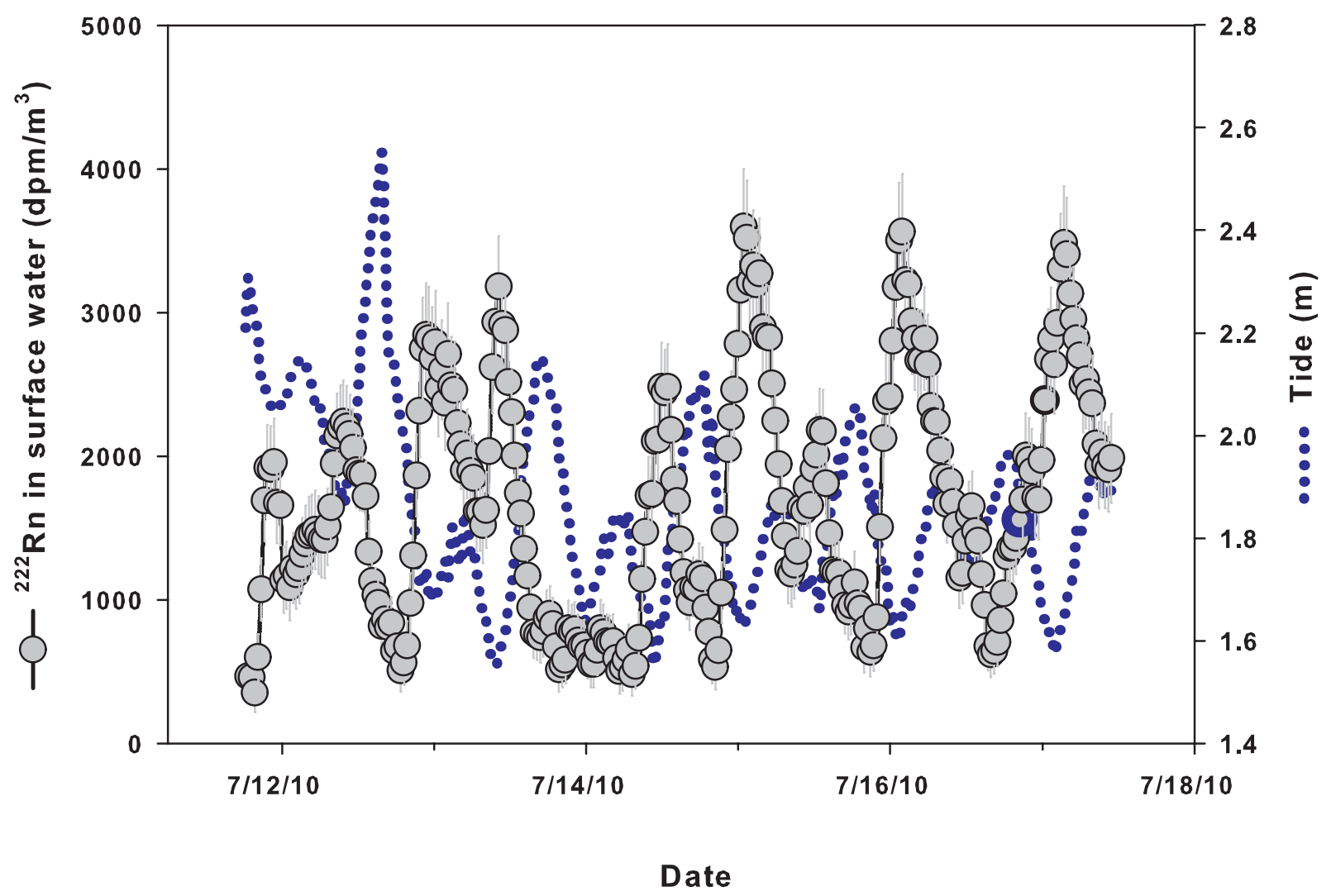

Figure 14. Time-series plots of surface water radon-222 (222Rn), in disintegrations per minute per cubic meter of water $\left(\mathrm{dpm} / \mathrm{m}^{3}\right)$, and water level, in meters $(\mathrm{m})$, at the primary submarine groundwater vent site. 


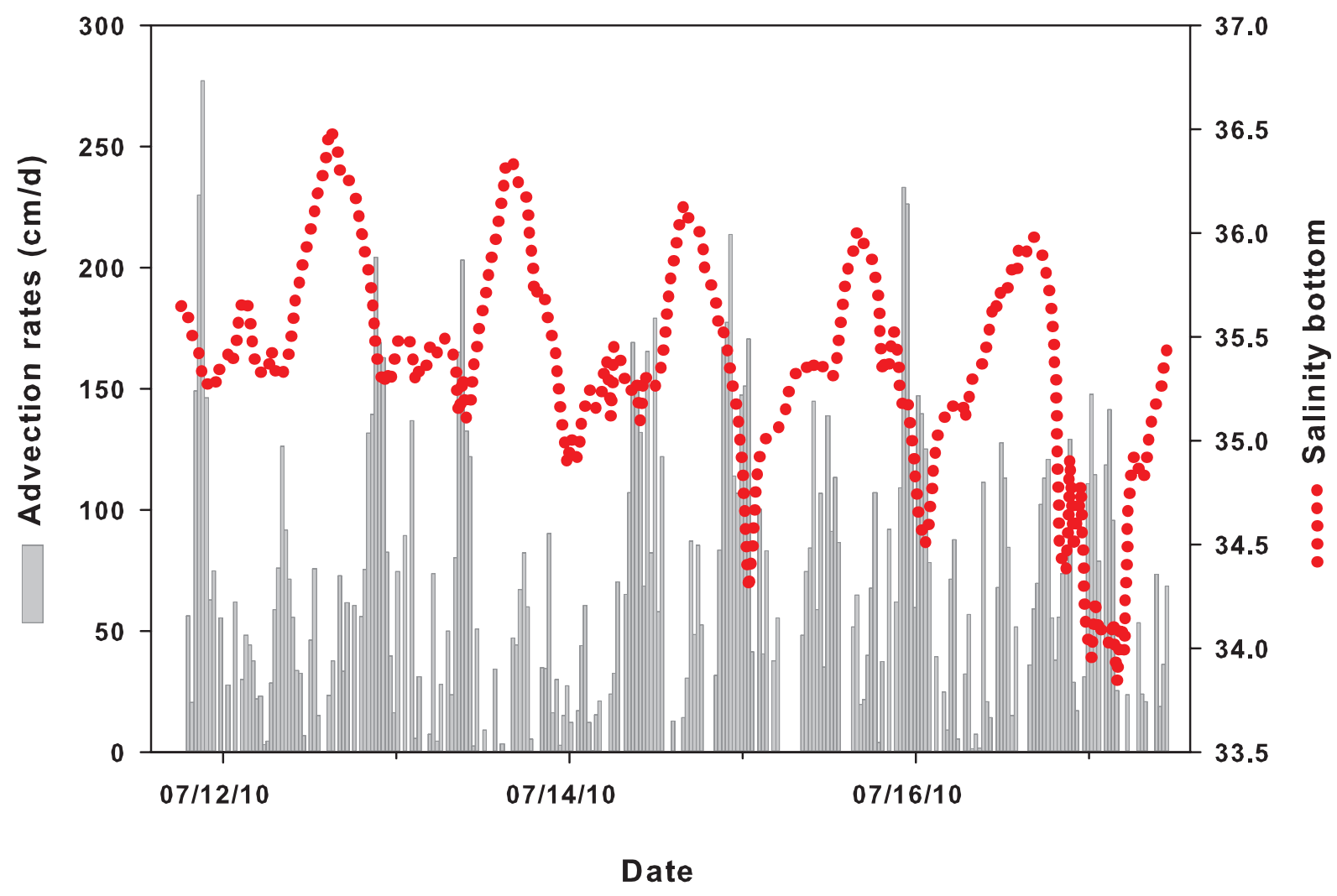

Figure 15. Time-series plots of calculated radon-222 (222Rn)-derived advection rates, in centimeters per day $(\mathrm{cm} / \mathrm{d})$, and salinity for the primary submarine groundwater vent site. 


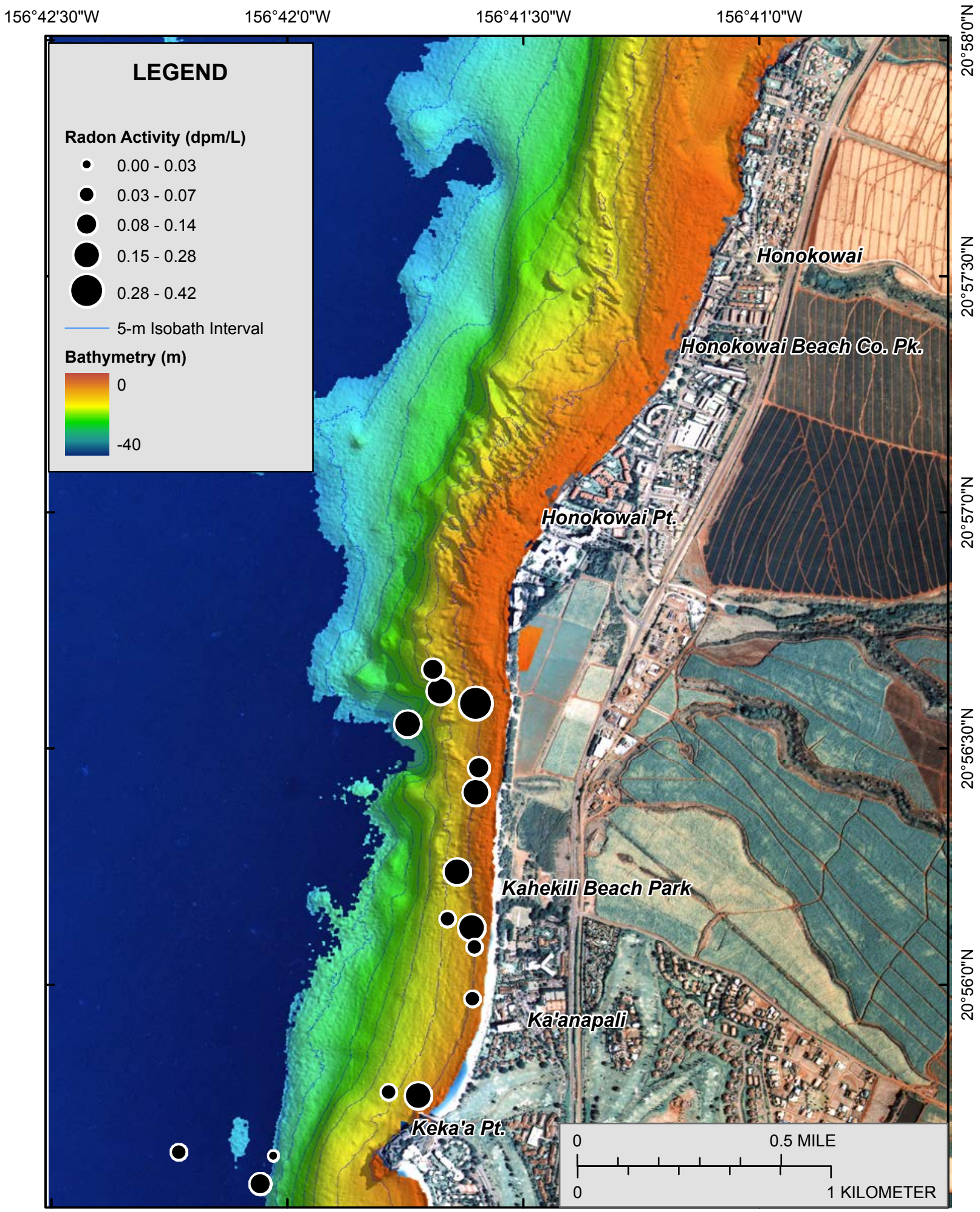

Figure 16. Aerial photograph and SHOALS (Scanning Hydrographic Operational Airborne Lidar Survey) lidar bathymetric map of the west Maui study area overlaid with radon-222 (222Rn) activities, in disintegrations per minute per liter of water (dpm/L), in coastal surface waters. $m$, meters. 

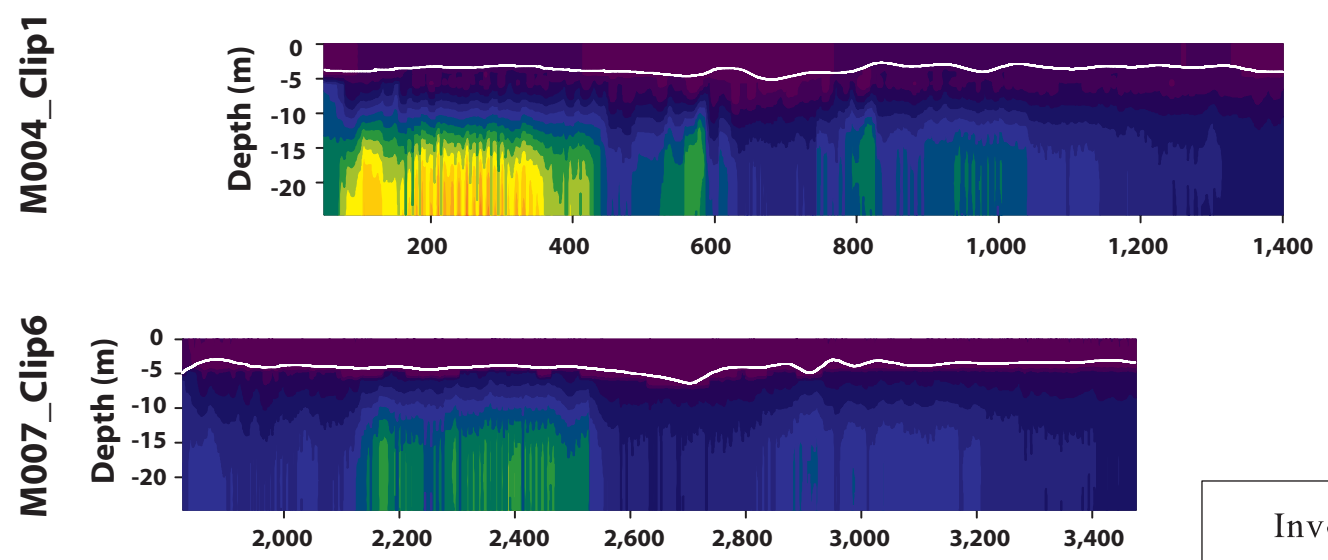

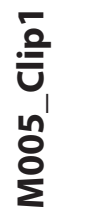

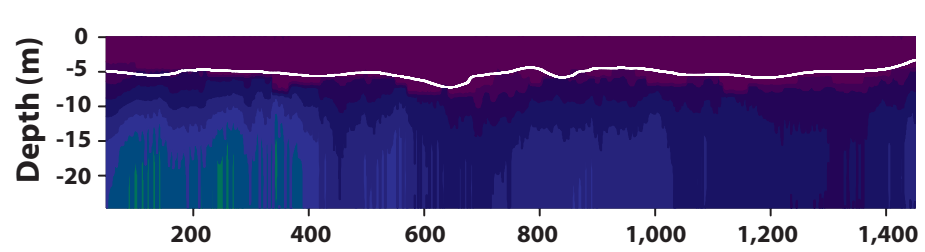

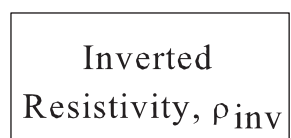

$(\Omega \bullet \mathrm{m})$

0.325

0.716

1.214

2.056

3.482

$\mathbf{5 . 8 9 7}$

13.00
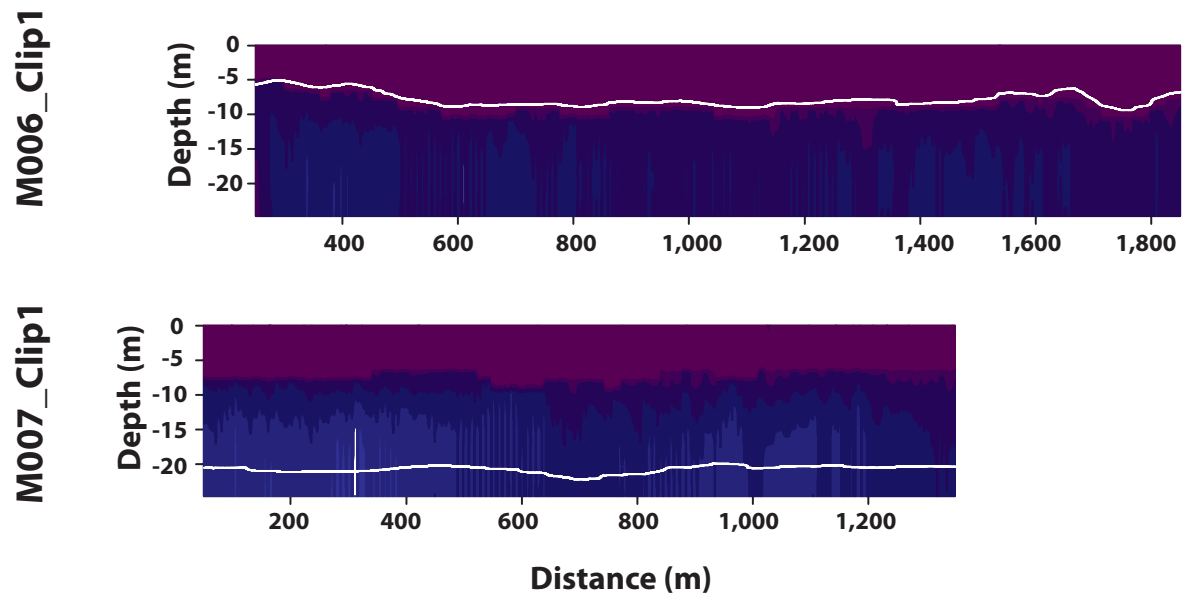

Figure 17. Fence diagrams showing continuous resistivity profile results from the shore-parallel transects in the west Maui study area. Transect line positions are shown in figure 4 . Warmer colors indicate higher resistivity (inverse of electrical conductivity) values, in ohm meters $(\Omega \cdot m)$. m, meters. 


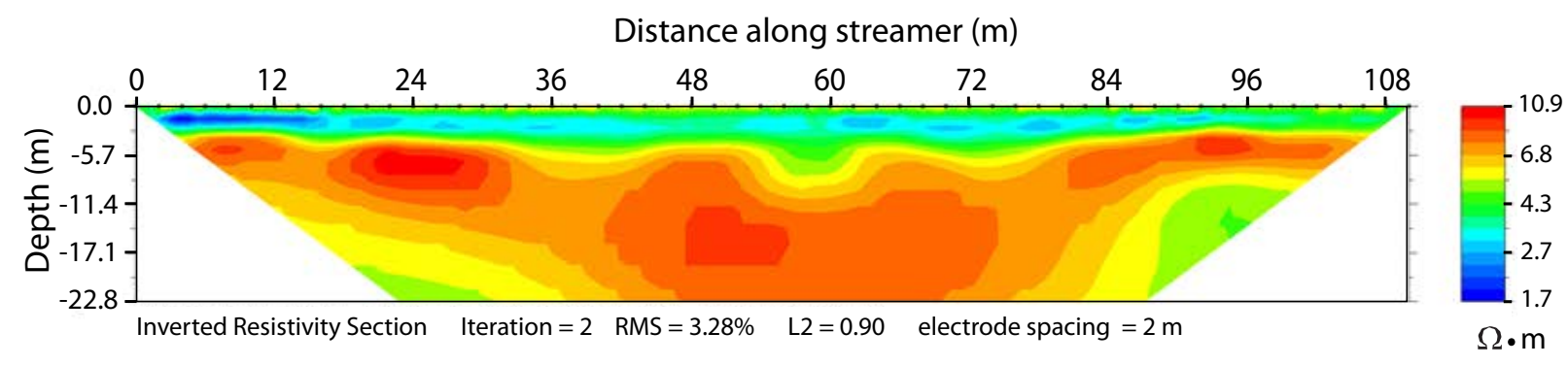

Figure 18. Fence diagram showing a land-based, multichannel electrical resistivity survey conducted along the beach face in the west Maui study area adjacent to the primary submarine groundwater vent site (horizontal axis is meters). Although resistivity values are influenced both by geologic and hydraulic parameters (Swarzenski and others 2007a,b), it is likely that the higher resistive layers observed define zones of enhanced hydrologic permeability. $\Omega \cdot \mathrm{m}$, ohm meters; $\mathrm{m}$, meters. 